\title{
LEVEL II SCOUR ANALYSIS FOR BRIDGE 17 (LYNDTH00020017) on TOWN HIGHWAY 2, crossing HAWKINS BROOK, LYNDON, VERMONT
}

Open-File Report 97-752

Prepared in cooperation with

VERMONT AGENCY OF TRANSPORTATION

and

FEDERAL HIGHWAY ADMINISTRATION

U.S. Department of the Interior U.S. Geological Survey

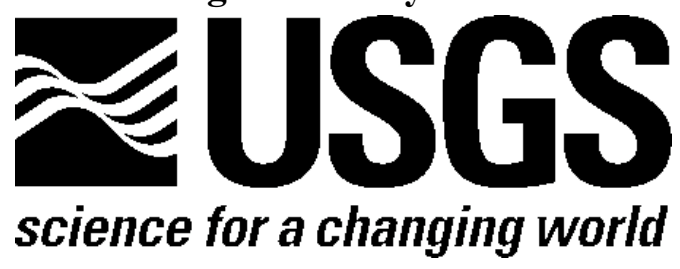




\section{LEVEL II SCOUR ANALYSIS FOR BRIDGE 17 (LYNDTH00020017) on TOWN HIGHWAY 2, crossing HAWKINS BROOK, LYNDON, VERMONT \\ By EMILY C. WILD and LAURA MEDALIE}

U.S. Geological Survey Open-File Report 97-752

Prepared in cooperation with

VERMONT AGENCY OF TRANSPORTATION

and

FEDERAL HIGHWAY ADMINISTRATION 


\title{
U.S. DEPARTMENT OF THE INTERIOR BRUCE BABBITT, Secretary
}

\author{
U.S. GEOLOGICAL SURVEY \\ Mark Schaefer, Acting Director
}

For additional information write to:

District Chief

U.S. Geological Survey 361 Commerce Way

Pembroke, NH 03275-3718
Copies of this report may be purchased from:

U.S. Geological Survey

Branch of Information Services

Open-File Reports Unit

Box 25286

Denver, CO 80225-0286 


\section{CONTENTS}

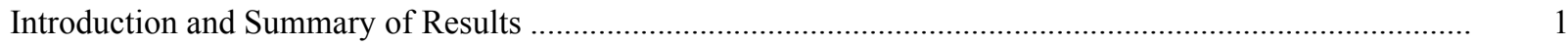

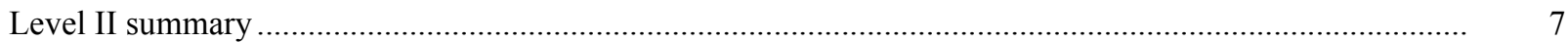

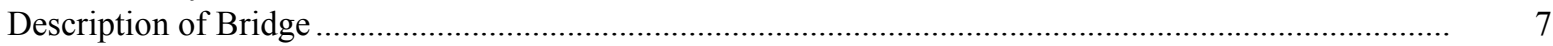

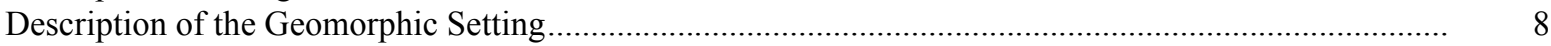

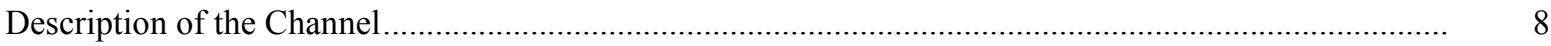

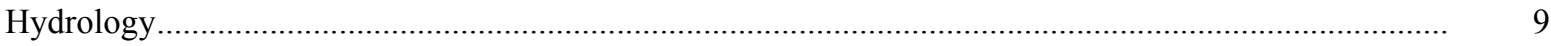

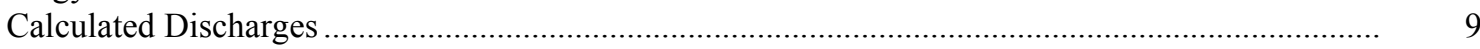

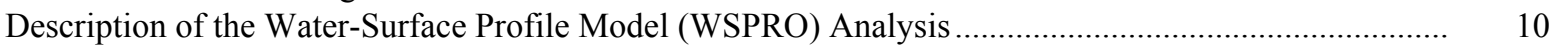

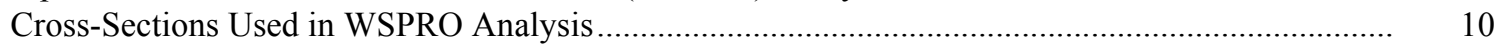

Data and Assumptions Used in WSPRO Model ...................................................................... 11

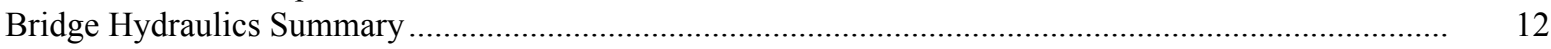

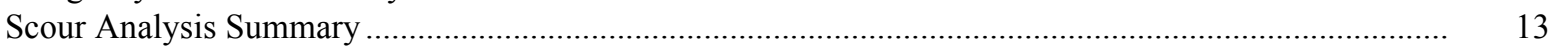

Special Conditions or Assumptions Made in Scour Analysis ...................................................... 13

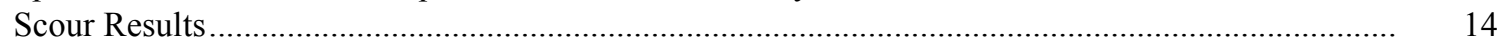

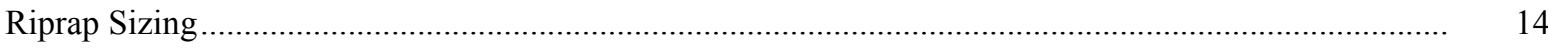

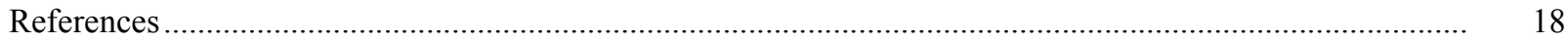

Appendixes:

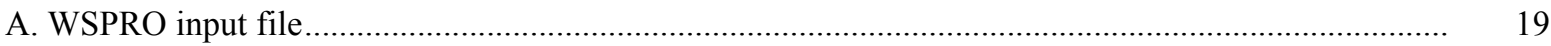

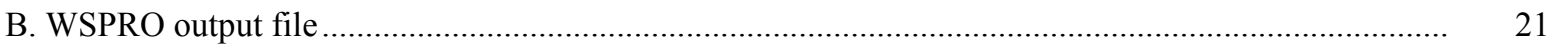

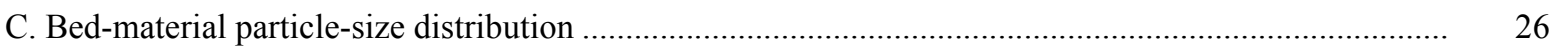

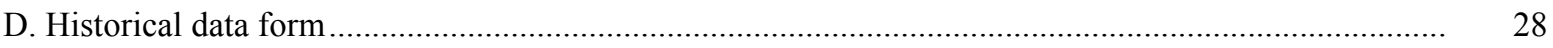

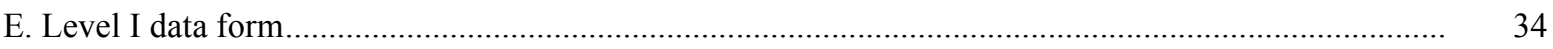

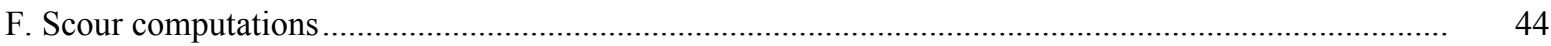

\section{FIGURES}

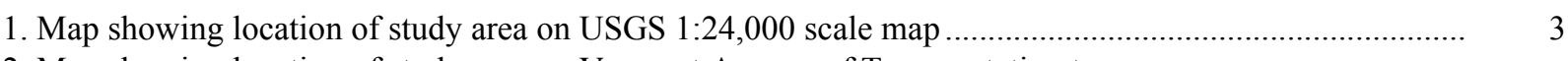

2. Map showing location of study area on Vermont Agency of Transportation town
highway map

3. Structure LYNDTH00020017 viewed from upstream (August 4, 1995) ............................................... 5

4. Downstream channel viewed from structure LYNDTH00020017 (August 4, 1995) ............................. 5

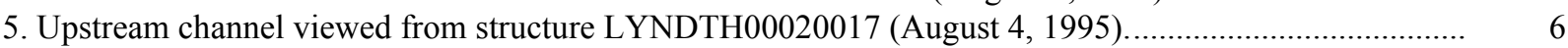

6. Structure LYNDTH00020017 viewed from downstream (August 4, 1995)....................................... 6

7. Water-surface profiles for the 100- and 500-year discharges at structure

LYNDTH00020017 on Town Highway 2, crossing Hawkins Brook,

Lyndon, Vermont.

8. Scour elevations for the 100- and 500-year discharges at structure

LYNDTH00020017 on Town Highway 2, crossing Hawkins Brook,

Lyndon, Vermont.

\section{TABLES}

1. Remaining footing/pile depth at abutments for the 100-year discharge at structure

LYNDTH00020017 on Town Highway 2, crossing Hawkins Brook,

Lyndon, Vermont.....

2. Remaining footing/pile depth at abutments for the 500-year discharge at structure

LYNDTH00020017 on Town Highway 2, crossing Hawkins Brook,

Lyndon, Vermont 


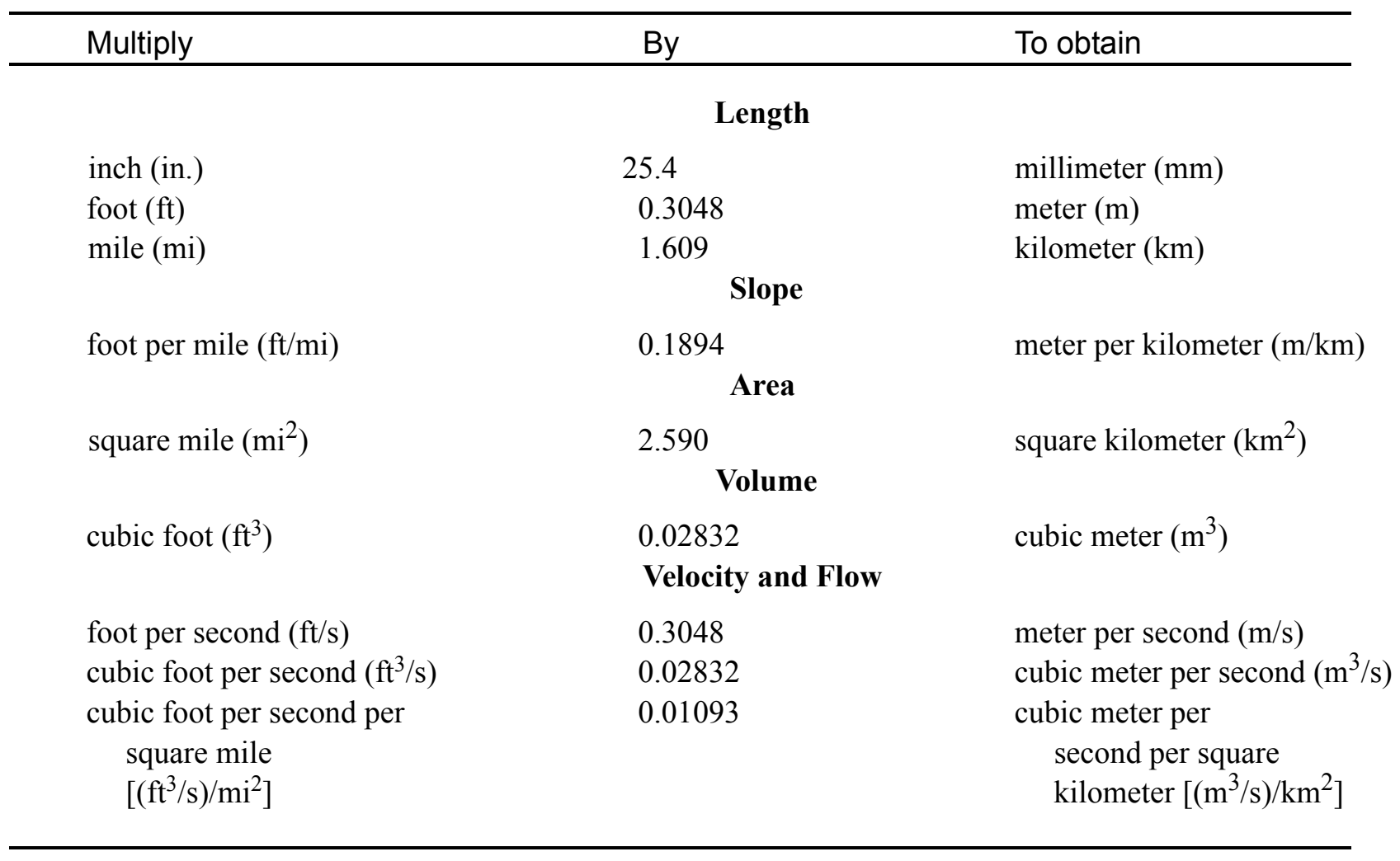

\section{OTHER ABBREVIATIONS}

$\begin{array}{lrlr}\mathrm{BF} & \text { bank full } & \text { LWW } & \text { left wingwall } \\ \mathrm{cfs} & \text { cubic feet per second } & \text { MC } & \text { main channel } \\ \mathrm{D}_{50} & \text { median diameter of bed material } & \text { RAB } & \text { right abutment } \\ \mathrm{DS} & \text { downstream } & \text { RABUT } & \text { face of right abutment } \\ \mathrm{elev} & \text { elevation } & \text { RB } & \text { right bank } \\ \mathrm{f} / \mathrm{p} & \text { flood plain } & \text { ROB } & \text { right overbank } \\ \mathrm{ft}^{2} & \text { square feet } & \text { RWW } & \text { right wingwall } \\ \mathrm{ft} / \mathrm{ft} & \text { feet per foot } & \text { TH } & \text { town highway } \\ \mathrm{JCT} & \text { junction } & \text { UB } & \text { under bridge } \\ \mathrm{LAB} & \text { left abutment } & \text { US } & \text { upstream } \\ \mathrm{LABUT} & \text { face of left abutment } & \text { USGS } & \text { United States Geological Survey } \\ \mathrm{LB} & \text { left bank } & \text { VTAOT Vermont Agency of Transportation } \\ \mathrm{LOB} & \text { left overbank } & \text { WSPRO } & \text { water-surface profile model }\end{array}$

In this report, the words "right" and "left" refer to directions that would be reported by an observer facing downstream. Sea level: In this report, "sea level" refers to the National Geodetic Vertical Datum of 1929-- a geodetic datum derived from a general adjustment of the first-order level nets of the United States and Canada, formerly called Sea Level Datum of 1929.

In the appendices, the above abbreviations may be combined. For example, USLB would represent upstream left bank. 


\title{
LEVEL II SCOUR ANALYSIS FOR BRIDGE 17 (LYNDTH00020017) ON TOWN HIGHWAY 2, CROSSING HAWKINS BROOK, LYNDON, VERMONT
}

\author{
By Emily C. Wild and Laura Medalie
}

\section{INTRODUCTION AND SUMMARY OF RESULTS}

This report provides the results of a detailed Level II analysis of scour potential at structure LYNDTH00020017 on Town Highway 2 crossing Hawkins Brook, Lyndon, Vermont (figures 1-8). A Level II study is a basic engineering analysis of the site, including a quantitative analysis of stream stability and scour (U.S. Department of Transportation, 1993). Results of a Level I scour investigation also are included in Appendix E of this report. A Level I investigation provides a qualitative geomorphic characterization of the study site. Information on the bridge, gleaned from Vermont Agency of Transportation (VTAOT) files, was compiled prior to conducting Level I and Level II analyses and is found in Appendix D.

The site is in the Green Mountain section of the New England physiographic province in northeastern Vermont. The $7.7-\mathrm{mi}^{2}$ drainage area is in a predominantly rural and forested basin. In the vicinity of the study site, the surface cover is forest on the left and right upstream overbanks. The downstream left and right overbanks are brushland.

In the study area, Hawkins Brook has an incised, sinuous channel with a slope of approximately $0.02 \mathrm{ft} / \mathrm{ft}$, an average channel top width of $78 \mathrm{ft}$ and an average bank height of $7.3 \mathrm{ft}$. The channel bed material ranges from sand to boulder with a median grain size $\left(\mathrm{D}_{50}\right)$ of $46.6 \mathrm{~mm}(0.153 \mathrm{ft})$. The geomorphic assessment at the time of the Level I and Level II site visit on August 4, 1995, indicated that the reach was laterally unstable with the presence of point bars and side bars.

The Town Highway 2 crossing of Hawkins Brook is a 49-ft-long, two-lane bridge consisting of a 46-foot steel-stringer span (Vermont Agency of Transportation, written communication, March 27, 1995). The opening length of the structure parallel to the bridge face is $43 \mathrm{ft}$. The bridge is supported by vertical, concrete abutments with wingwalls. The channel is skewed approximately 45 degrees to the opening while the computed openingskew-to-roadway is zero degrees. 
A scour hole $0.75 \mathrm{ft}$ deeper than the mean thalweg depth was observed along the downstream left abutment during the Level I assessment. The only scour protection measure at the site was type- 2 stone fill (less than 36 inches diameter) at the upstream end of the downstream left wingwall. Additional details describing conditions at the site are included in the Level II Summary and Appendices D

and $\mathrm{E}$.

Scour depths and recommended rock rip-rap sizes were computed using the general guidelines described in Hydraulic Engineering Circular 18 (Richardson and others, 1995) for the 100- and 500-year discharges. Total scour at a highway crossing is comprised of three components: 1) long-term streambed degradation; 2) contraction scour (due to accelerated flow caused by a reduction in flow area at a bridge) and; 3 ) local scour (caused by accelerated flow around piers and abutments). Total scour is the sum of the three components. Equations are available to compute depths for contraction and local scour and a summary of the results of these computations follows.

Contraction scour for all modelled flows ranged from 0.1 to $0.9 \mathrm{ft}$. The worst-case contraction scour occurred at the 500-year discharge. Abutment scour ranged from 3.8 to $6.6 \mathrm{ft}$. The worst-case abutment scour occurred at the 500-year discharge. Additional information on scour depths and depths to armoring are included in the section titled "Scour Results". Scoured-streambed elevations, based on the calculated scour depths, are presented in tables 1 and 2. A cross-section of the scour computed at the bridge is presented in figure 8. Scour depths were calculated assuming an infinite depth of erosive material and a homogeneous particle-size distribution.

It is generally accepted that the Froehlich equation (abutment scour) gives "excessively conservative estimates of scour depths" (Richardson and others, 1995, p. 47). Usually, computed scour depths are evaluated in combination with other information including (but not limited to) historical performance during flood events, the geomorphic stability assessment, existing scour protection measures, and the results of the hydraulic analyses. Therefore, scour depths adopted by VTAOT may differ from the computed values documented herein. 


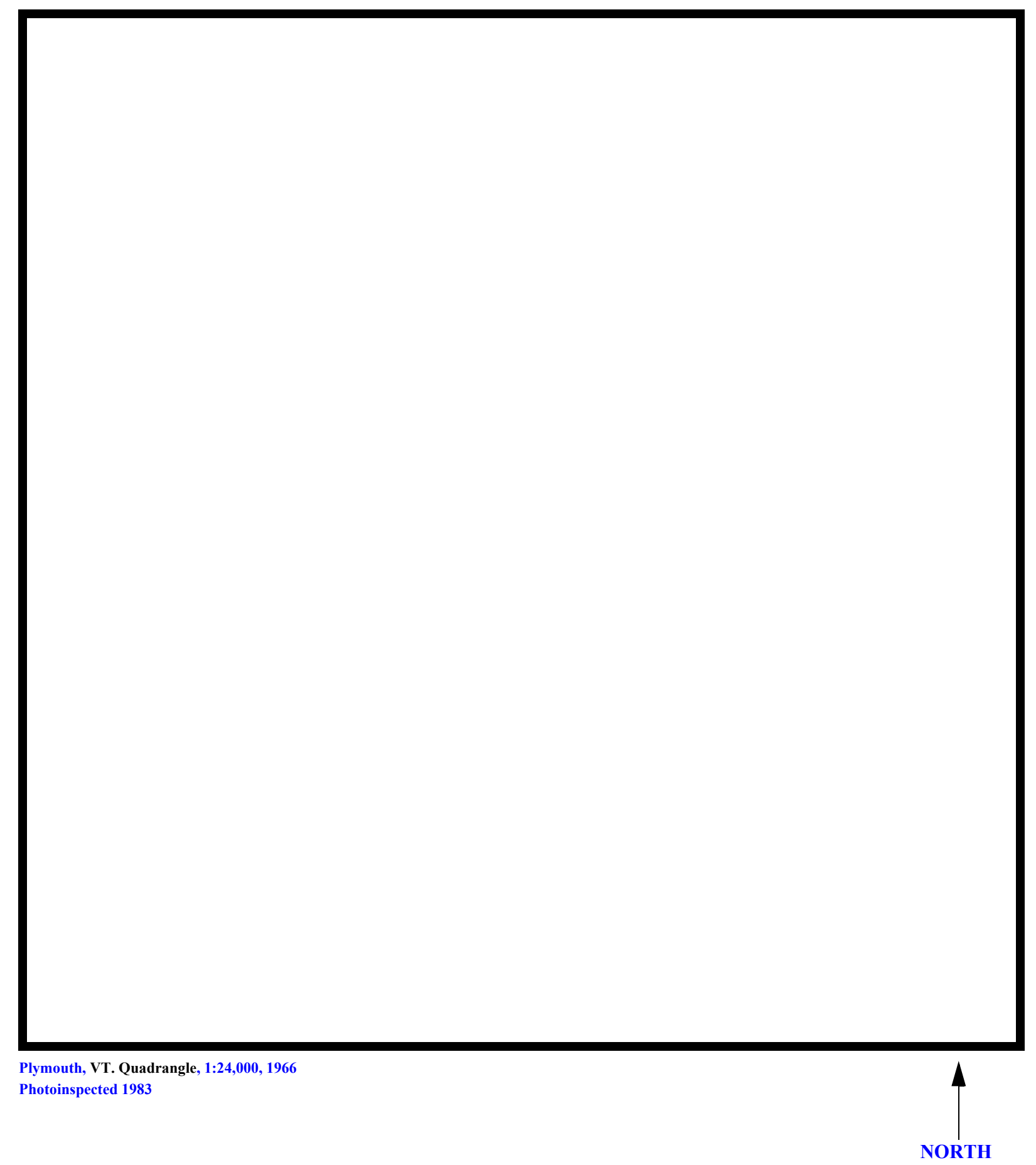

Figure 1. Location of study area on USGS 1:24,000 scale map. 
Figure 2. Location of study area on Vermont Agency of Transportation town highway map. 

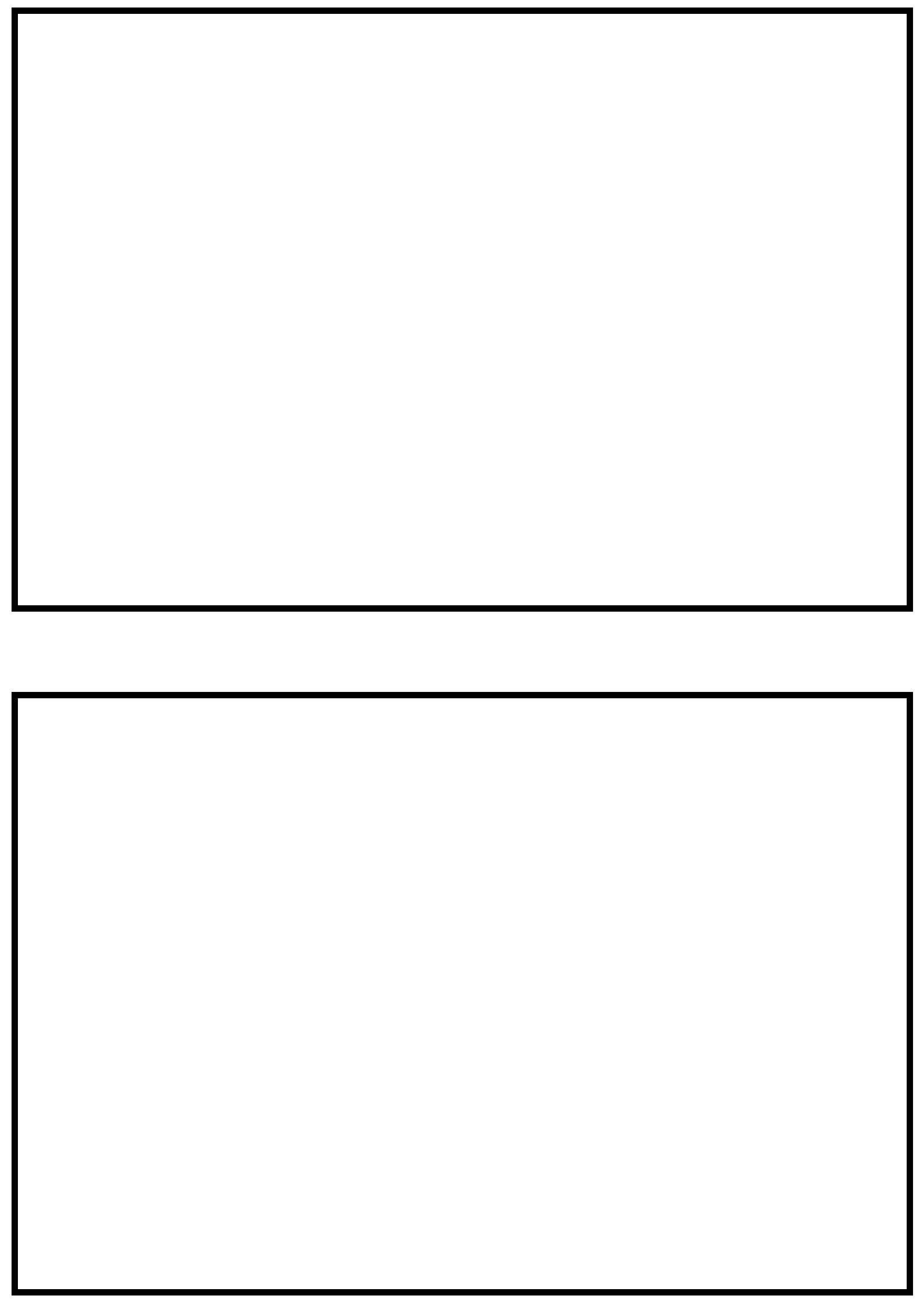

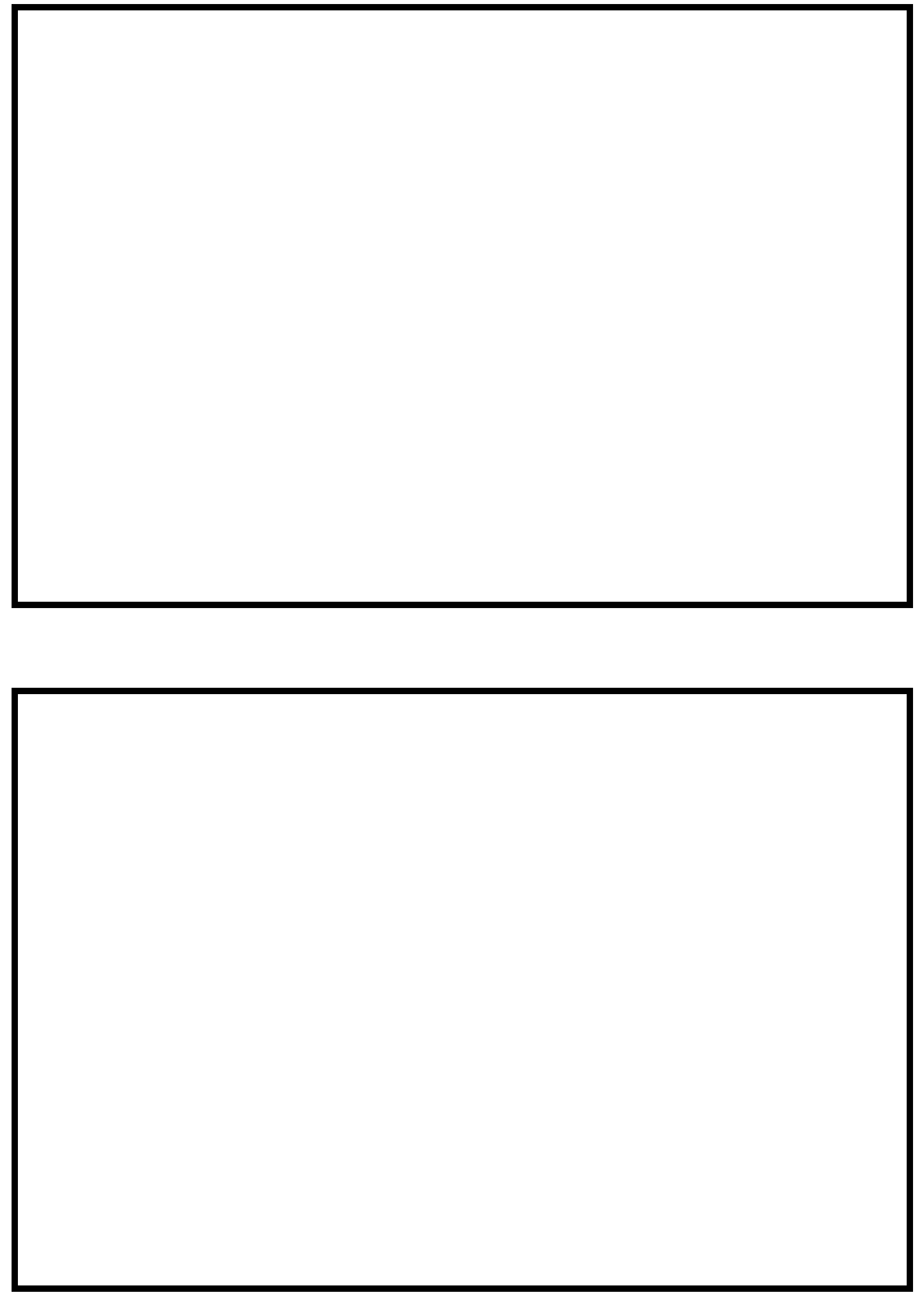


\section{LEVEL II SUMMARY}

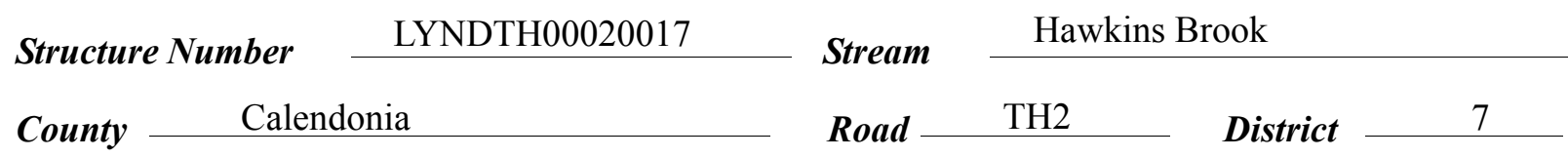

\section{Description of Bridge}

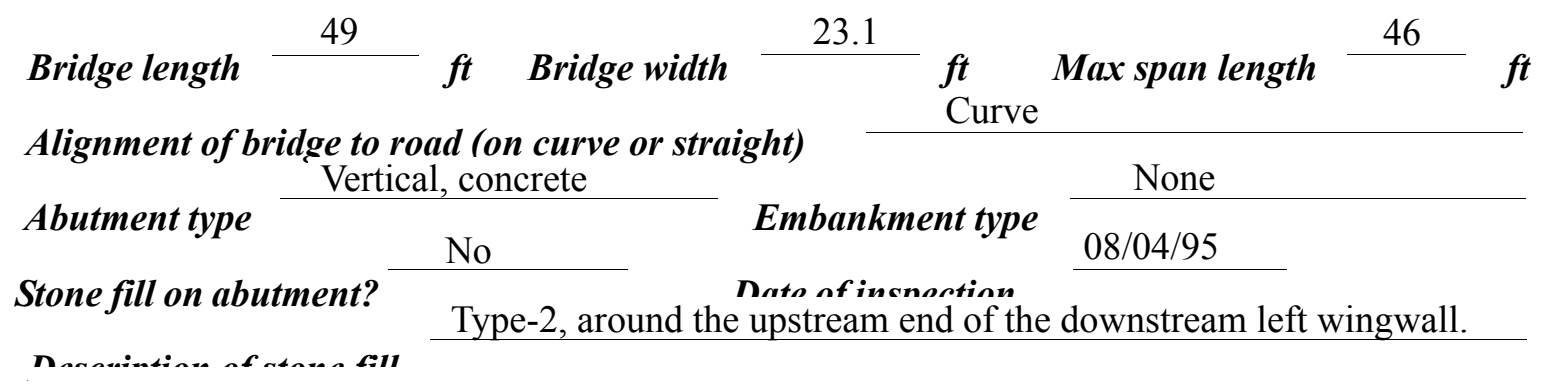

Abutments and wingwalls are concrete. There is a 0.75 foot deep scour hole in front of the upstream left abutment.

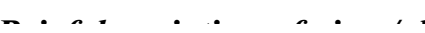

45

Y

Is bridge skewed to flood flow according to There ' survey?

Angle

is a mild channel bend in the upstream reach.

Debris accumulation on bridge at time of Level I or Level II site visit:

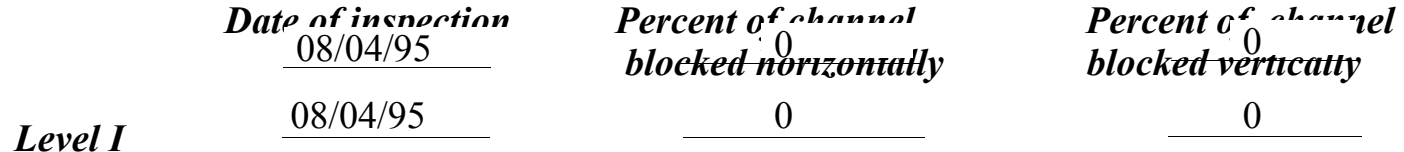

Level II

Low. There is some debris caught on the boulders in the channel upstream, and on the I-beams under the bridge.

Potential for debris

None (8/04/95).

Doscriho anv, foaturos noar ar at tho hridos that mav, affoct flou, (includo ahsorvation dato) 


\section{Description of the Geomorphic Setting}

General topography The channel is located within a moderately sloped valley.

Geomorphic conditions at bridge site: downstream (DS), upstream (US)

Date of inspection $\quad 08 / 04 / 95$

DS left: $\quad$ Narrow flood plain.

DS right: $\quad$ Moderately sloped overbank.

US left: $\quad$ Moderately sloped overbank.

US right: Narrow flood plain.

\section{Description of the Channel}

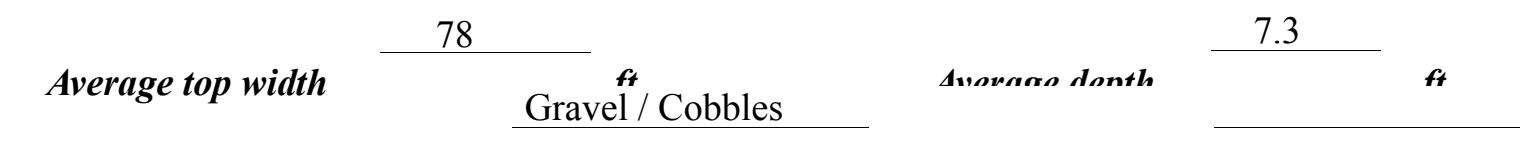

Predominant bed material

Bank material

Cobbles/Boulders

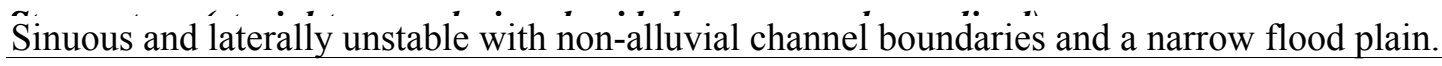

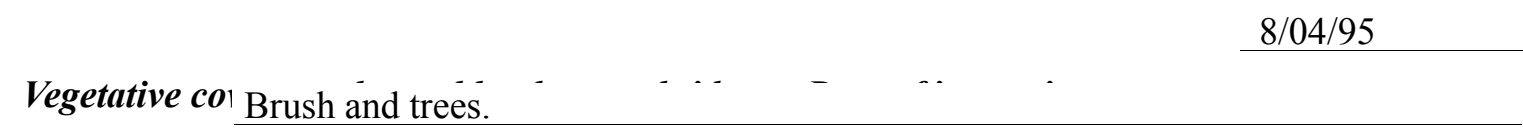

DS left: $\quad$ Brush and trees.

DS right: Trees.

US left: $\quad$ Trees with some brush.

US right: $\quad \underline{\mathrm{N}}$

Do banks appear stable? Banks are laterally unstable especially where a moderate channel. impact zone is present along the upstream left bank.

The assessment of $8 /$

04/95 noted a few boulders on the left bank side of the channel under the bridge, and some piles Describe any obstructions in channel and date of observation.

of cobbles along the right abutment. 


\section{Hydrology}

Drainage area $\frac{7.7}{m i^{2}}$

Percentage of drainage area in physiographic provinces: (approximate)

Physiographic province/section

New England/Green Mountain
Percent of drainage area 100

Is drainage area considered rural or urban? Rural Describe any significant urbanization:

Is there a USGS gage on the stream of interest?

No

USGS gage description

USGS gage number

Gage drainage area $\mathrm{mi}^{2}$

No

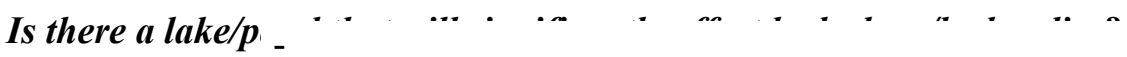

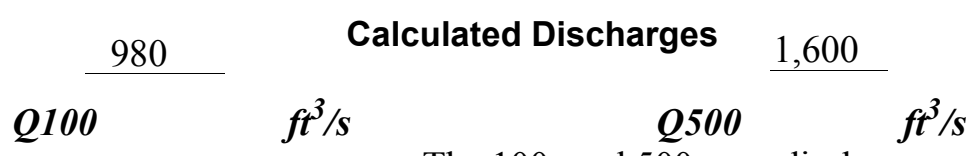

The 100- and 500-year discharges are based on a

drainage area relationship [(7.7/11.5/exp 0.7] with Flood Insurance Study discharge values for the Town of Lyndon at the confluence with the Passumpic River (Federal Emergency

Management Agency, 1988). Hawkins Brook enters the Passumpic River downstream of this bridge site. These values are within a range defined by several empirical flood frequency curves (Benson, 1962; Johnson and Tasker, 1974; FHWA, 1983; Potter, 1957a\&b; Talbot, 1887). 


\section{Description of the Water-Surface Profile Model (WSPRO) Analysis}

Datum for WSPRO analysis (USGS survey, sea level, VTAOT plans)

USGS survey

Datum tie between USGS survey and VTAOT plans

None

Description of reference marks used to determine USGS datum. $\quad$ RM1 is a chiseled X on top of the upstream end of the left abutment (elev. $499.89 \mathrm{ft}$, arbitrary survey datum). RM2 is a chiseled X on top of the downstream end of the right abutment (elev. $501.67 \mathrm{ft}$, arbitrary survey datum).

\section{Cross-Sections Used in WSPRO Analysis}

\begin{tabular}{|c|c|c|c|}
\hline${ }^{1}$ Cross-section & $\begin{array}{c}\text { Section } \\
\text { Reference } \\
\text { Distance } \\
\text { (SRD) in feet }\end{array}$ & $\begin{array}{c}{ }^{2} \text { Cross-section } \\
\text { development }\end{array}$ & Comments \\
\hline EXIT1 & -58 & 1 & Exit section \\
\hline FULLV & 0 & 2 & $\begin{array}{l}\text { Downstream Full-valley } \\
\text { section (Templated from } \\
\text { EXIT1) }\end{array}$ \\
\hline BRIDG & 0 & 1 & Bridge section \\
\hline RDWAY & 12 & 1 & Road Grade section \\
\hline APPRO & 68 & 2 & $\begin{array}{l}\text { Modelled Approach sec- } \\
\text { tion (Templated from } \\
\text { APTEM) }\end{array}$ \\
\hline APTEM & 80 & 1 & $\begin{array}{l}\text { Approach section as sur- } \\
\text { veyed (Used as a tem- } \\
\text { plate) }\end{array}$ \\
\hline
\end{tabular}

${ }^{1}$ For location of cross-sections see plan-view sketch included with Level I field form, Appendix E. For more detail on how cross-sections were developed see WSPRO input file. 


\section{Data and Assumptions Used in WSPRO Model}

Hydraulic analyses of the reach were done by use of the Federal Highway Administration's WSPRO step-backwater computer program (Shearman and others, 1986, and Shearman, 1990). The analyses reported herein reflect conditions existing at the site at the time of the study. Furthermore, in the development of the model it was necessary to assume no accumulation of debris or ice at the site. Results of the hydraulic model are presented in the Bridge Hydraulic Summary, Appendix B, and figure 7.

Channel roughness factors (Manning's “ $n$ ”) used in the hydraulic model were estimated using field inspections at each cross section following the general guidelines described by Arcement and Schneider (1989). Final adjustments to the values were made during the modelling of the reach. Channel " $\mathrm{n}$ " values for the reach ranged from 0.055 to 0.060 , and overbank " $\mathrm{n}$ " values ranged from 0.050 to 0.080 .

Normal depth at the exit section (EXIT1) was assumed as the starting water surface. This depth was computed by use of the slope-conveyance method outlined in the user's manual for WSPRO (Shearman, 1990). The slope used was $0.02 \mathrm{ft} / \mathrm{ft}$, which was estimated from the topographic map (U.S. Geological Survey, 1988).

The surveyed approach section (APTEM) was moved along the approach channel slope $(0.029 \mathrm{ft} / \mathrm{ft})$ to establish the modelled approach section (APPRO), one bridge length upstream of the upstream face as recommended by Shearman and others (1986). This location also provides a consistent method for determining scour variables. 


\section{Bridge Hydraulics Summary}

\begin{tabular}{llll} 
Average bridge embankment elevation & 501.0 \\
\cline { 3 - 3 } Average low steel elevation & 497.5 & $\boldsymbol{f t}$
\end{tabular}

100-year discharge $\quad 980 \quad \mathrm{ft}^{3} / \mathrm{s}$

Water-surface elevation in bridge opening $\quad 491.9 \quad f t$

Road overtopping? ___ N Discharge over road ___-- $\mathrm{ft}^{3} / \mathrm{s}$

Area of flow in bridge opening $\quad 122 \quad \mathrm{ft}^{2}$

Average velocity in bridge opening $\quad 8.0 \quad \mathrm{ft} / \mathrm{s}$

Maximum WSPRO tube velocity at bridge $\quad 10.7 \mathrm{ft} / \mathrm{s}$

Water-surface elevation at Approach section with bridge 493.9

Water-surface elevation at Approach section without bridge $\quad 493.5$

Amount of backwater caused by bridge

0.4 it

500-year discharge $\quad 1,600 \quad \mathrm{ft}^{3} / \mathrm{s}$

Water-surface elevation in bridge opening

$492.6 f t$

Road overtopping? ___ N Discharge over road ___ -- $f^{3} / \mathrm{s}$

Area of flow in bridge opening $\quad 152 \quad \mathrm{ft}^{2}$

Average velocity in bridge opening $10.6 \mathrm{ft} / \mathrm{s}$

Maximum WSPRO tube velocity at bridge 13.6 's

Water-surface elevation at Approach section with bridge 495.7

Water-surface elevation at Approach section without bridge $\quad 494.3$

Amount of backwater caused by bridge 1.4 , $t$

Incipient overtopping discharge _ $\quad \mathrm{N} \quad f t^{3} / \mathrm{s}$

Water-surface elevation in bridge opening $\quad--\quad t$

Area of flow in bridge opening _ -- $\mathrm{ft}^{2}$

Average velocity in bridge opening $\quad--\quad f t / s$

Maximum WSPRO tube velocity at bridge __ -- $\mathrm{ft} / \mathrm{s}$

Water-surface elevation at Approach section with bridge

Water-surface elevation at Approach section without bridge

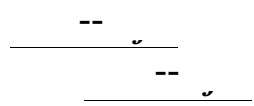

Amount of backwater caused by bridge _ - - it 


\section{Scour Analysis Summary}

\section{Special Conditions or Assumptions Made in Scour Analysis}

Scour depths were computed using the general guidelines described in Hydraulic Engineering Circular 18 (Richardson and others, 1995). Scour depths were calculated assuming an infinite depth of erosive material and a homogeneous particle-size distribution. The results of the scour analysis are presented in tables 1 and 2 and a graph of the scour depths is presented in figure 8 .

Contraction scour for the 100-year and 500-year discharges was computed by use of the Laursen clear-water contraction scour equation (Richardson and others, 1995, p. 32, equation 20). At this site, the 100-year and 500-year discharges resulted in free-surface bridge flow. The computed streambed armoring depths suggest that armoring will not limit the depth of contraction scour.

Abutment scour was computed by use of the Froehlich equation (Richardson and others, 1995, p. 48, equation 28). Variables for the Froehlich equation include the Froude number of the flow approaching the embankments, the length of the embankment blocking flow, and the depth of flow approaching the embankment less any roadway overtopping. 


\section{Scour Results}

\section{0-yr discharge 500-yr discharge}

Contraction scour:

(Scour depths in feet)

Main channel

Live-bed scour

Clear-water scour

Depth to armoring

Left overbank

Right overbank

Local scour:

Abutment scour

Left abutment

Right abutment

Pier scour

Pier 1

Pier 2

Pier 3

5.2

$3.8-$
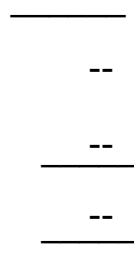

6.6

$6.0-$
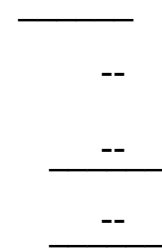

Incipient overtopping discharge 


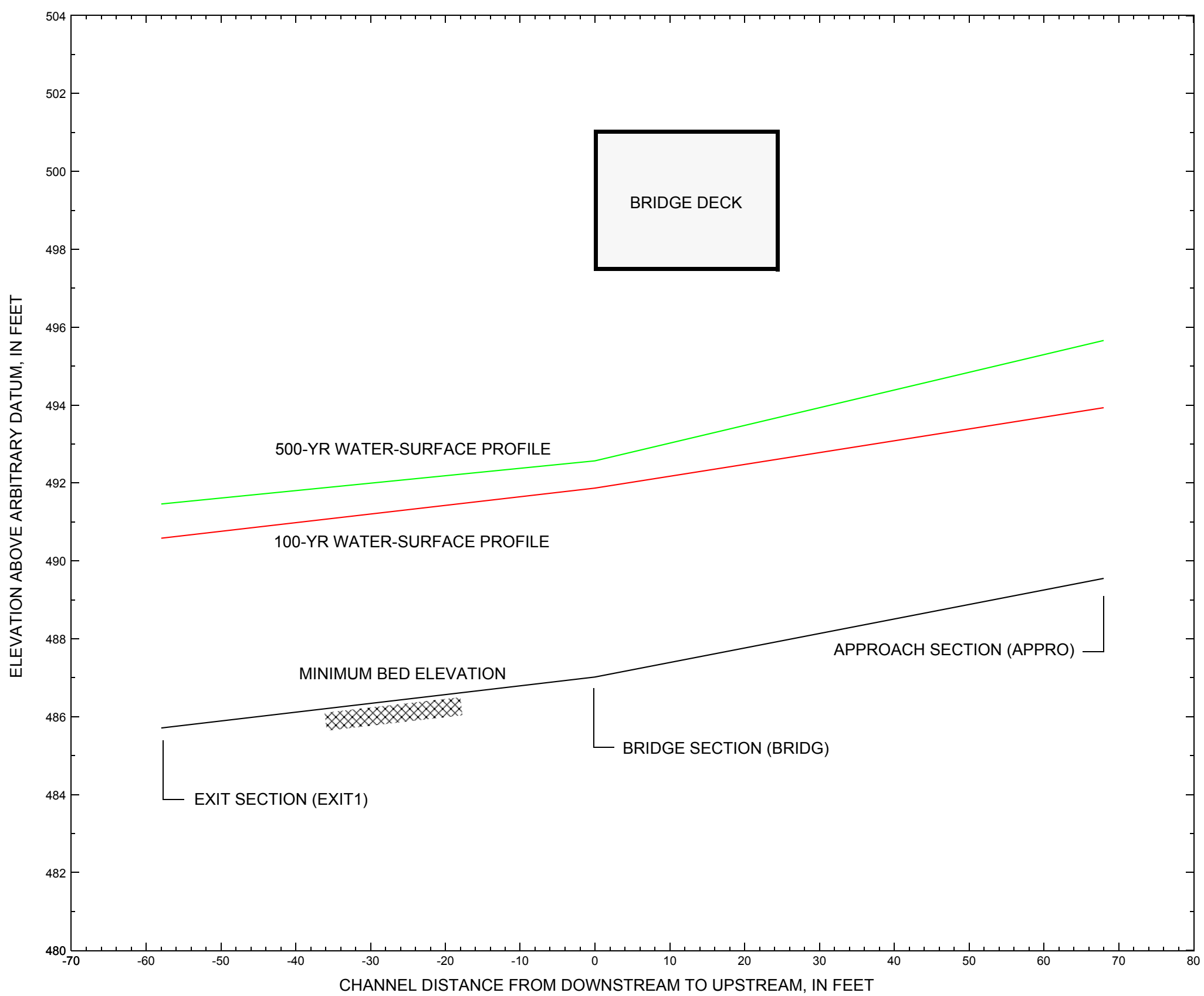

Figure 7. Water-surface profiles for the 100- and 500-yr discharges at structure LYNDTH00020017 on Town Highway 2, crossing Hawkins Brook, Lyndon, Vermont. 


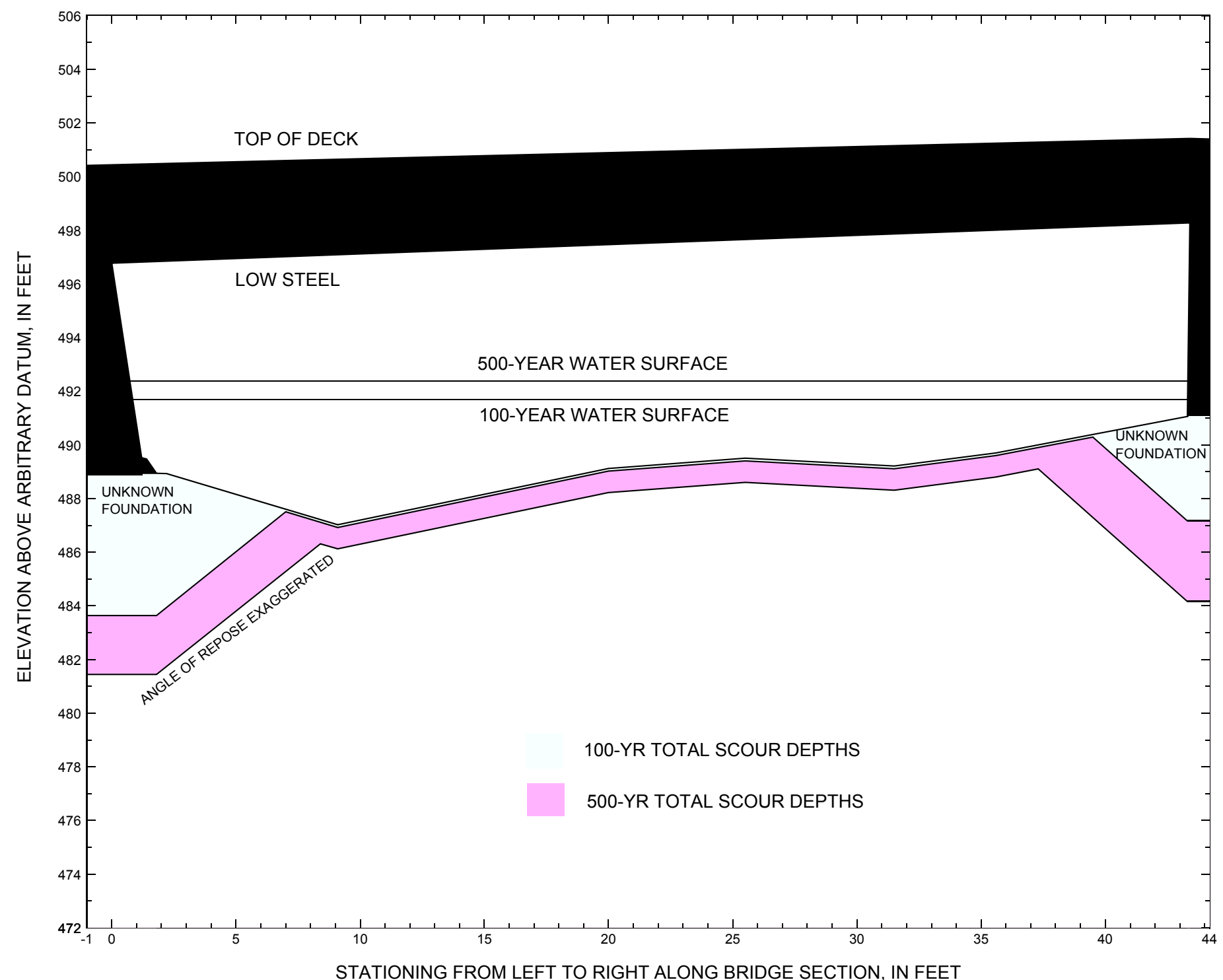

Figure 8. Scour elevations for the 100-yr and 500-yr discharges at structure LYNDTH00020017 on Town Highway 2, crossing Hawkins Brook, Lyndon, Vermont. 
Table 1. Remaining footing/pile depth at abutments for the 100-year discharge at structure LYNDTH00020017 on Town Highway 2, crossing Hawkins Brook, Lyndon, Vermont.

[VTAOT, Vermont Agency of Transportation; --,no data]

\begin{tabular}{|c|c|c|c|c|c|c|c|c|c|c|c|}
\hline Description & Station $^{1}$ & $\begin{array}{l}\text { VTAOT } \\
\text { minimum } \\
\text { low-chord } \\
\text { elevation } \\
\text { (feet) }\end{array}$ & $\begin{array}{c}\text { Surveyed } \\
\text { minimum } \\
\text { low-chord } \\
\text { elevation } \\
\text { (feet) }\end{array}$ & $\begin{array}{c}\text { Bottom of } \\
\text { footing/pile } \\
\text { elevation } \\
\text { (feet) }\end{array}$ & $\begin{array}{l}\text { Channel } \\
\text { elevation at } \\
\text { abutment/ } \\
\text { pier }^{2} \\
\text { (feet) }\end{array}$ & $\begin{array}{l}\text { Contraction } \\
\text { scour depth } \\
\text { (feet) }\end{array}$ & $\begin{array}{l}\text { Abutment } \\
\text { scour } \\
\text { depth } \\
\text { (feet) }\end{array}$ & $\begin{array}{l}\text { Pier } \\
\text { scour } \\
\text { depth } \\
\text { (feet) }\end{array}$ & $\begin{array}{l}\text { Depth of } \\
\text { total scour } \\
\text { (feet) }\end{array}$ & $\begin{array}{c}\text { Elevation of } \\
\text { scour }^{2} \\
\text { (feet) }\end{array}$ & $\begin{array}{c}\text { Remaining } \\
\text { footing/pile } \\
\text { depth } \\
\text { (feet) }\end{array}$ \\
\hline \multicolumn{12}{|c|}{100 -yr. discharge is 980 cubic-feet per second } \\
\hline Left abutment & 0.0 & -- & 496.8 & -- & 488.9 & 0.1 & 5.2 & -- & 5.3 & 483.6 & -- \\
\hline Right abutment & 43.4 & -- & 498.3 & -- & 491.1 & 0.1 & 3.8 & -- & 3.9 & 487.2 & -- \\
\hline
\end{tabular}

1.Measured along the face of the most constricting side of the bridge.

2.Arbitrary datum for this study.

Table 2. Remaining footing/pile depth at abutments for the 500-year discharge at structure LYNDTH00020017 on Town Highway 2, crossing Hawkins Brook, Lyndon, Vermont.

[VTAOT, Vermont Agency of Transportation; --, no data]

\begin{tabular}{|c|c|c|c|c|c|c|c|c|c|c|c|}
\hline Description & Station $^{1}$ & $\begin{array}{l}\text { VTAOT } \\
\text { minimum } \\
\text { low-chord } \\
\text { elevation } \\
\text { (feet) }\end{array}$ & $\begin{array}{c}\text { Surveyed } \\
\text { minimum } \\
\text { low-chord } \\
\text { elevation } \\
\text { (feet) }\end{array}$ & $\begin{array}{c}\text { Bottom of } \\
\text { footing/pile } \\
\text { elevation } \\
\text { (feet) }\end{array}$ & $\begin{array}{c}\text { Channel } \\
\text { elevation at } \\
\text { abutment/ } \\
\text { pier }^{2} \\
\text { (feet) }\end{array}$ & $\begin{array}{l}\text { Contraction } \\
\text { scour depth } \\
\text { (feet) }\end{array}$ & $\begin{array}{c}\text { Abutment } \\
\text { scour } \\
\text { depth } \\
\text { (feet) }\end{array}$ & $\begin{array}{l}\text { Pier } \\
\text { scour } \\
\text { depth } \\
\text { (feet) }\end{array}$ & $\begin{array}{l}\text { Depth of } \\
\text { total scour } \\
\text { (feet) }\end{array}$ & $\begin{array}{c}\text { Elevation of } \\
\text { scour }^{2} \\
\text { (feet) }\end{array}$ & $\begin{array}{c}\text { Remaining } \\
\text { footing/pile } \\
\text { depth } \\
\text { (feet) }\end{array}$ \\
\hline \multicolumn{12}{|c|}{500 -yr. discharge is 1,600 cubic-feet per second } \\
\hline Left abutment & 0.0 & -- & 496.8 & -- & 488.9 & 0.9 & 6.6 & -- & 7.5 & 481.4 & -- \\
\hline Right abutment & 43.4 & -- & 498.3 & -- & 491.1 & 0.9 & 6.0 & -- & 6.9 & 484.2 & -- \\
\hline
\end{tabular}

1.Measured along the face of the most constricting side of the bridge.

2.Arbitrary datum for this study. 


\section{SELECTED REFERENCES}

Arcement, G.J., Jr., and Schneider, V.R., 1989, Guide for selecting Manning's roughness coefficients for natural channels and flood plains:

U.S. Geological Survey Water-Supply Paper 2339, 38 p.

Barnes, H.H., Jr., 1967, Roughness characteristics of natural channels: U.S. Geological Survey Water-Supply Paper 1849,213 p.

Benson, M. A., 1962, Factors Influencing the Occurrence of Floods in a Humid Region of Diverse Terrain: U.S. Geological Survey WaterSupply Paper 1580-B, 64 p.

Brown, S.A. and Clyde, E.S., 1989, Design of riprap revetment: Federal Highway Administration Hydraulic Engineering Circular No. 11, Publication FHWA-IP-89-016, 156 p.

Federal Highway Administration, 1983, Runoff estimates for small watersheds and development of sound design: Federal Highway Administration Report FHWA-RD-77-158.

Federal Highway Administration, 1993, Stream Stability and Scour at Highway Bridges: Participant Workbook: Federal Highway Administration Report FHWA-HI-91-011.

Federal Emergency Management Agency, 1988, Flood Insurance Study, Town of Lyndon, Caldonia County, Vermont: Washington, D.C., May 17, 1988.

Froehlich, D.C., 1989, Local scour at bridge abutments in Ports, M.A., ed., Hydraulic Engineering--Proceedings of the 1989 National Conference on Hydraulic Engineering: New York, American Society of Civil Engineers, p. 13-18.

Hayes, D.C.,1993, Site selection and collection of bridge-scour data in Delaware, Maryland, and Virginia: U.S. Geological Survey WaterResources Investigation Report 93-4017, 23 p.

Interagency Advisory Committee on Water Data, 1982, Guidelines for determining flood flow frequency: U.S. Geological Survey, Bulletin 17B of the Hydrology Subcommittee, 190 p.

Johnson, C.G. and Tasker, G.D.,1974, Progress report on flood magnitude and frequency of Vermont streams: U.S. Geological Survey OpenFile Report 74-130, 37 p.

Lagasse, P.F., Schall, J.D., Johnson, F., Richardson, E.V., Chang, F., 1995, Stream Stability at Highway Structures: Federal Highway Administration Hydraulic Engineering Circular No. 20, Publication FHWA-IP-90-014, 144 p.

Laursen, E.M., 1960, Scour at bridge crossings: Journal of the Hydraulics Division, American Society of Civil Engineers, v. 86, no. HY2, p. 39-53.

Potter, W. D., 1957a, Peak rates of runoff in the Adirondack, White Mountains, and Maine woods area, Bureau of Public Roads

Potter, W. D., 1957b, Peak rates of runoff in the New England Hill and Lowland area, Bureau of Public Roads

Richardson, E.V. and Davis, S.R., 1995, Evaluating scour at bridges: Federal Highway Administration Hydraulic Engineering Circular No. 18, Publication FHWA-IP-90-017, 204 p.

Richardson, E.V., Simons, D.B., and Julien, P.Y., 1990, Highways in the river environment: Federal Highway Administration Publication FHWA-HI-90-016.

Ritter, D.F., 1984, Process Geomorphology: W.C. Brown Co., Debuque, Iowa, 603 p.

Shearman, J.O., 1990, User's manual for WSPRO--a computer model for water surface profile computations: Federal Highway Administration Publication FHWA-IP-89-027, 187 p.

Shearman, J.O., Kirby, W.H., Schneider, V.R., and Flippo, H.N., 1986, Bridge waterways analysis model; research report: Federal Highway Administration Publication FHWA-RD-86-108, 112 p.

Talbot, A.N., 1887, The determination of water-way for bridges and culverts.

U.S. Department of Transportation, 1993, Stream stability and scour at highway bridges, Participant Workbook: Federal Highway Administration Publication FHWA HI-91-011.

U.S. Geological Survey, 1988, Burke Mountain, Vermont 7.5 Minute Series quadrangle map: U.S. Geological Survey Topographic Maps, Scale 1:24,000. 


\section{APPENDIX A: \\ WSPRO INPUT FILE}




\section{WSPRO INPUT FILE}

GR

GR

GR

GR

GR

GR

GR

$N$

SA

*

*

$\mathrm{XS}$

*

*

BR

GR

GR

GR

GR

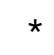

CD

$\mathrm{N}$

*

*

*

XR

GR

GR

*

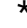

$\mathrm{XT}$

GR

GR

GR

GR

*

AS

GT

$\mathrm{N}$

SA
U.S. Geological Survey WSPRO Input File lynd017.wsp Hydraulic analysis for structure LYNDTH00020017 Date: 17-JUL-97 Town Highway 2, Hawkins Brook, Lyndon, Vermont

ECW

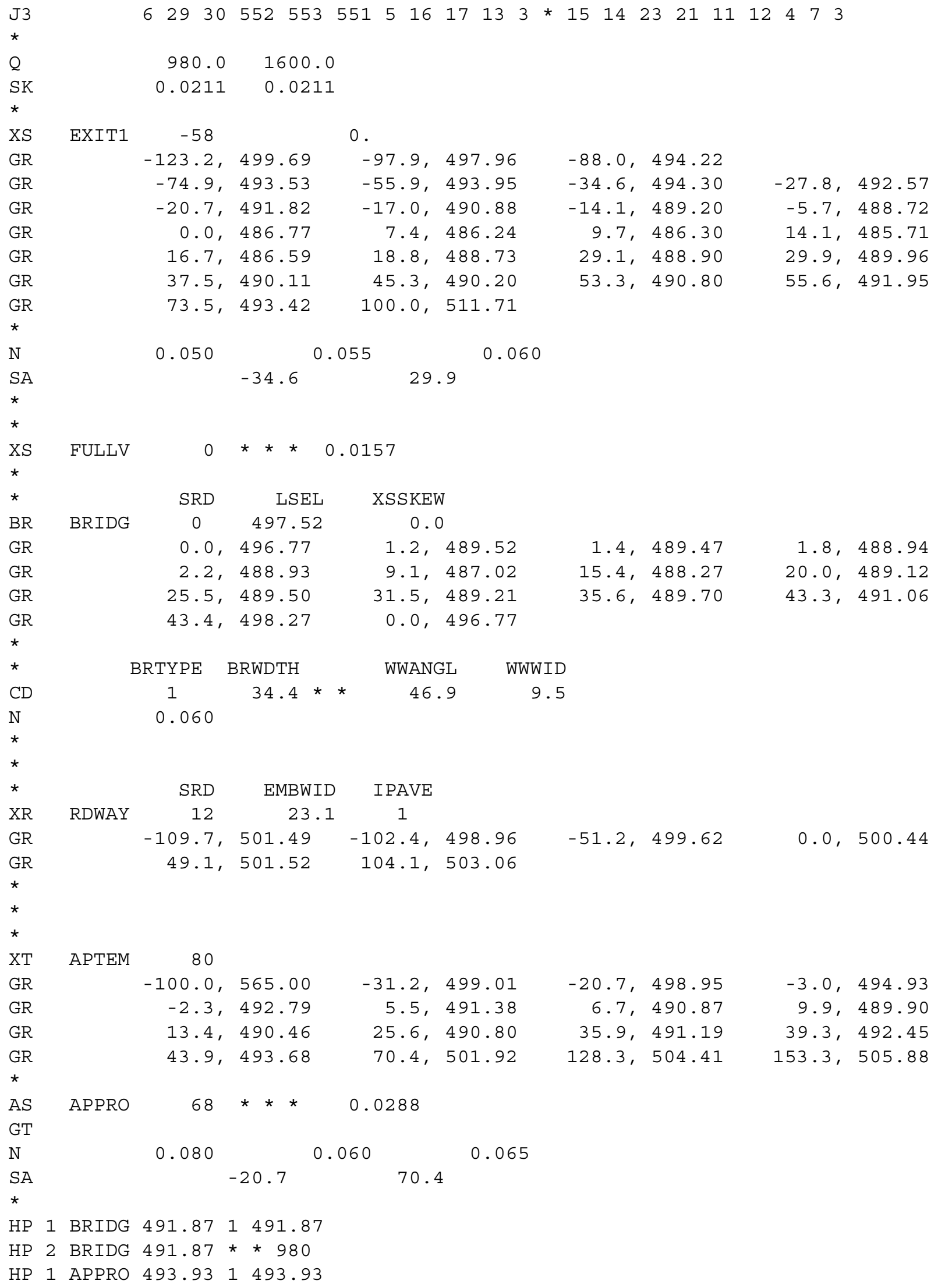




\section{APPENDIX B: \\ WSPRO OUTPUT FILE}




\section{WSPRO OUTPUT FILE}

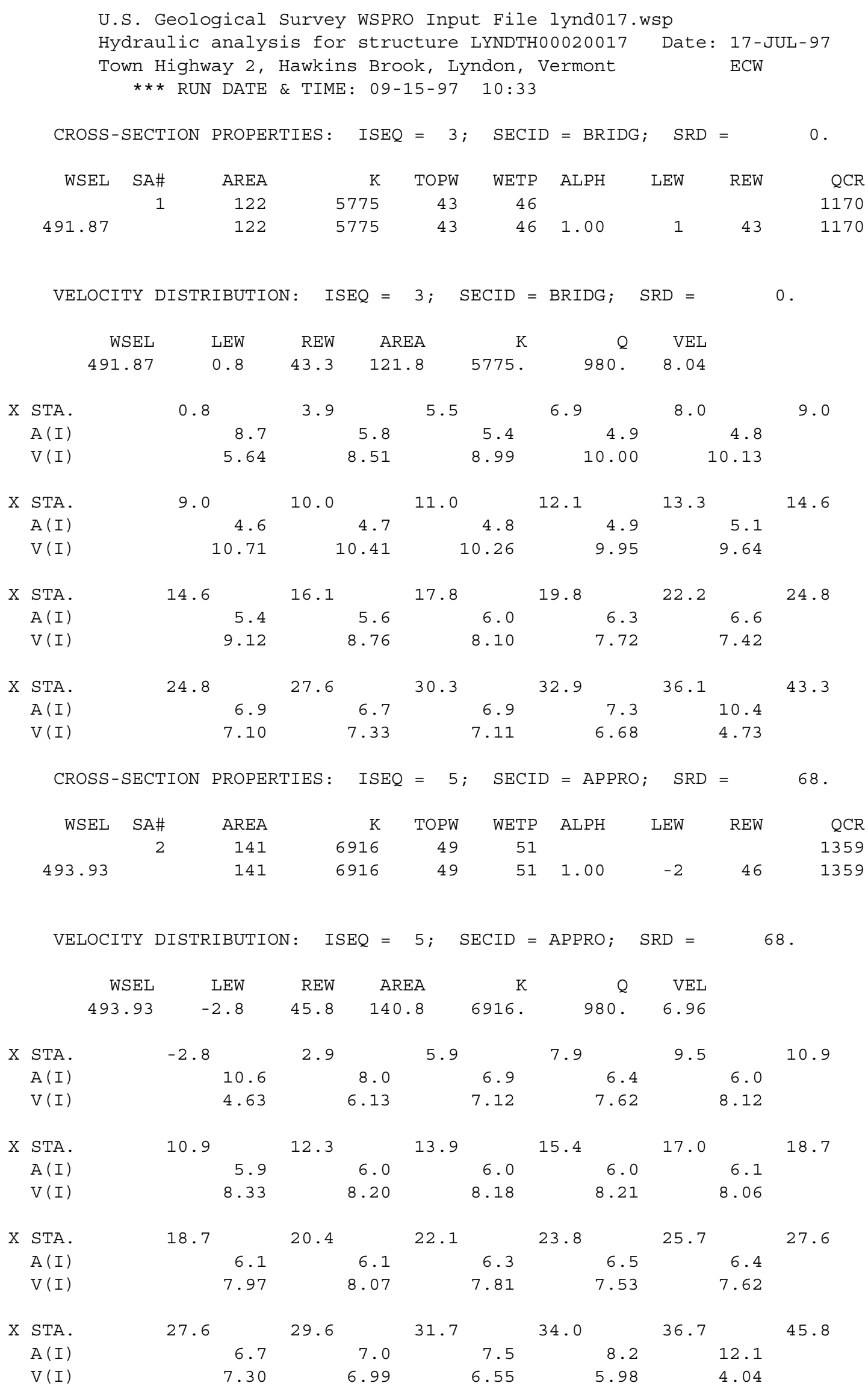




\section{WSPRO OUTPUT FILE (continued)}

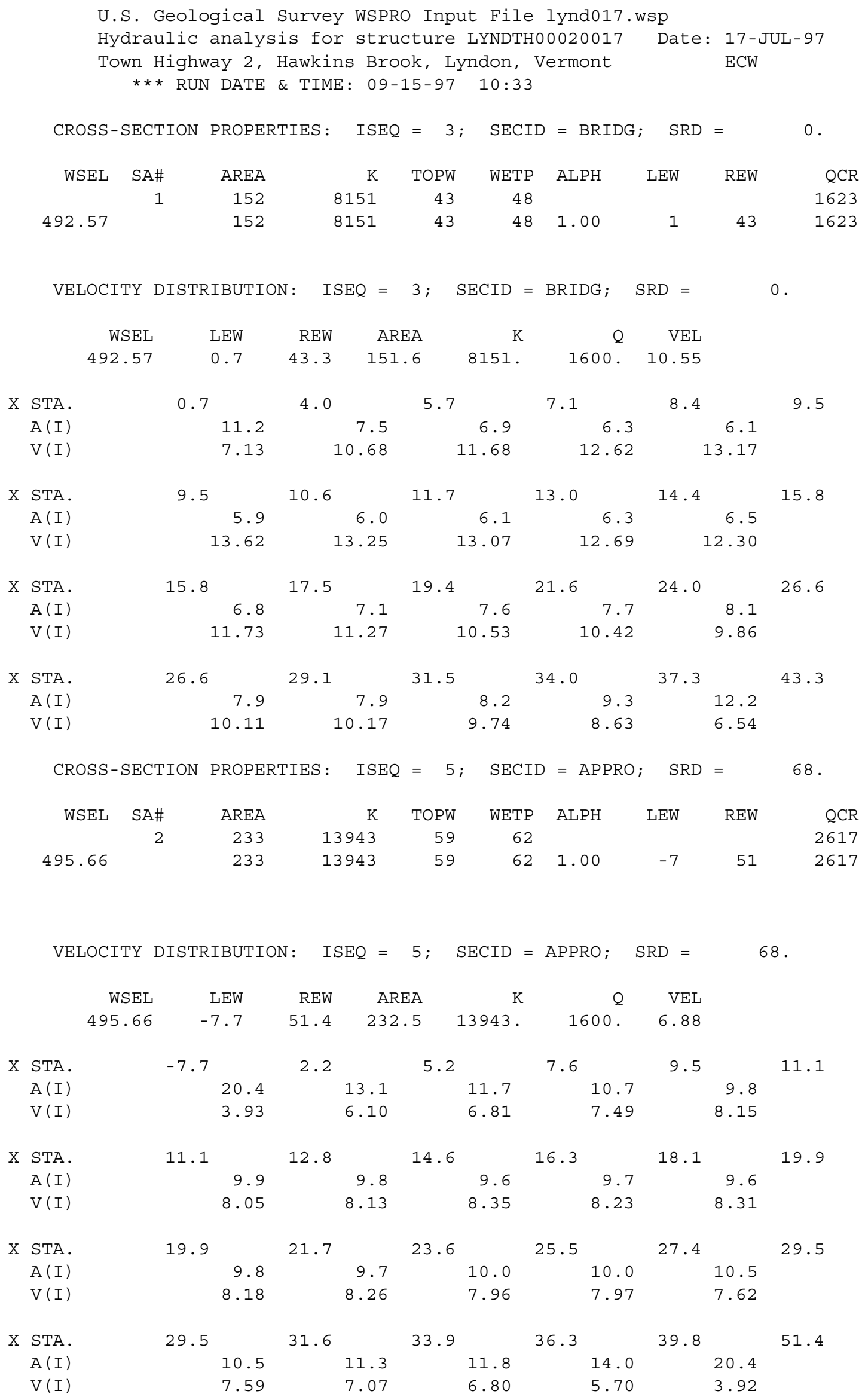




\section{WSPRO OUTPUT FILE (continued)}

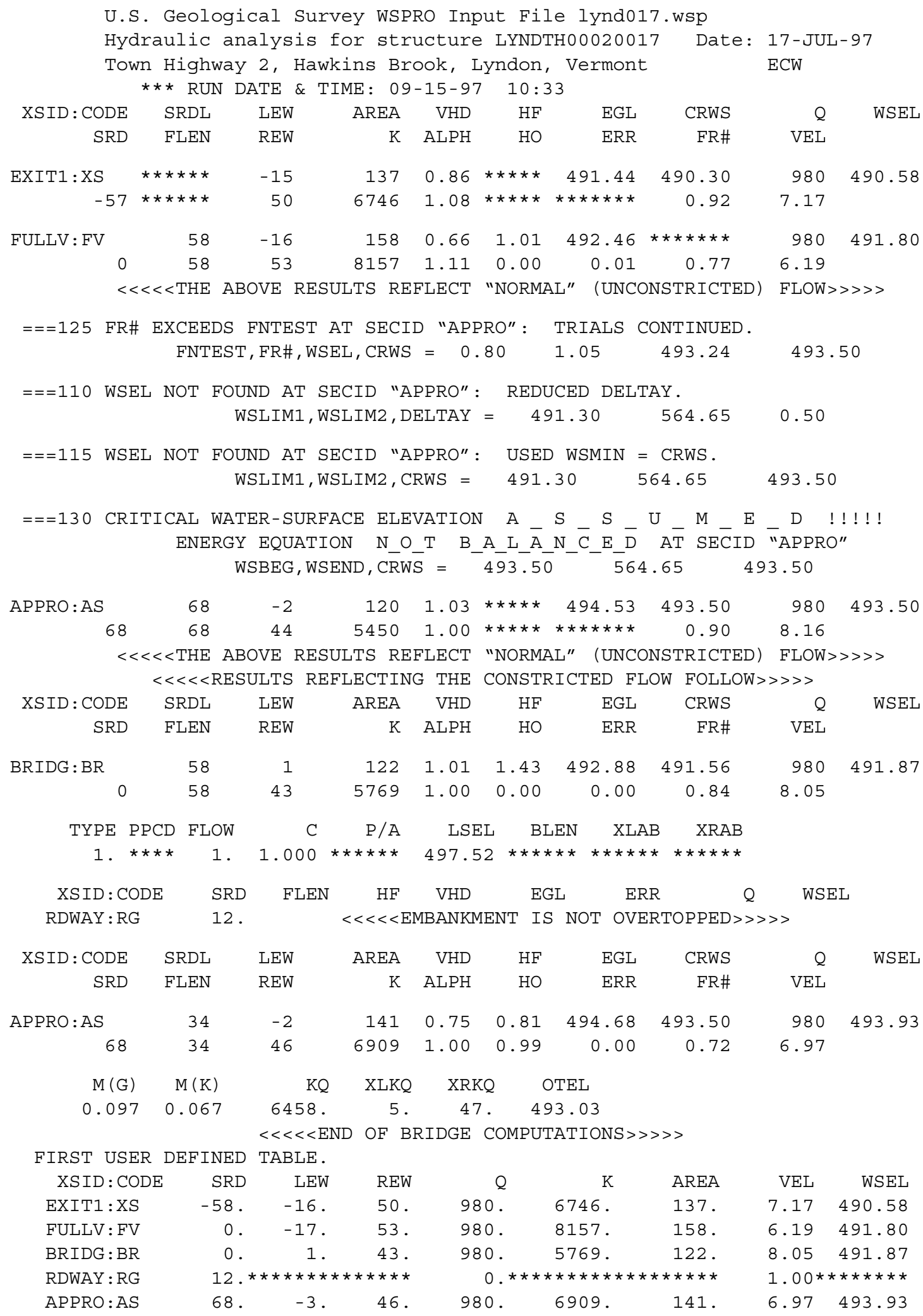

SECOND USER DEFINED TABLE.

$\begin{array}{lrrrrrrrrr}\text { XSID : CODE } & \text { CRWS } & \text { FR\# } & \text { YMIN } & \text { YMAX } & \text { HF } & \text { HO } & \text { VHD } & \text { EGL } & \text { WSEL } \\ \text { EXIT1 :XS } & 490.30 & 0.92 & 485.71 & 511.71 * * * * * * * * * * * & 0.86 & 491.44 & 490.58 \\ \text { FULLV : FV } & * * * * * * * & 0.77 & 486.62 & 512.62 & 1.01 & 0.00 & 0.66 & 492.46 & 491.80 \\ \text { BRIDG : BR } & 491.56 & 0.84 & 487.02 & 498.27 & 1.43 & 0.00 & 1.01 & 492.88 & 491.87 \\ \text { RDWAY : RG } & * * * * * * * * * * * * * * * & 498.96 & 503.06 * * * * * * * * * * * * * * * * * * * * * * * * * * * * * * \\ \text { APPRO :AS } & 493.50 & 0.72 & 489.55 & 564.65 & 0.81 & 0.99 & 0.75 & 494.68 & 493.93\end{array}$




\section{WSPRO OUTPUT FILE (continued)}

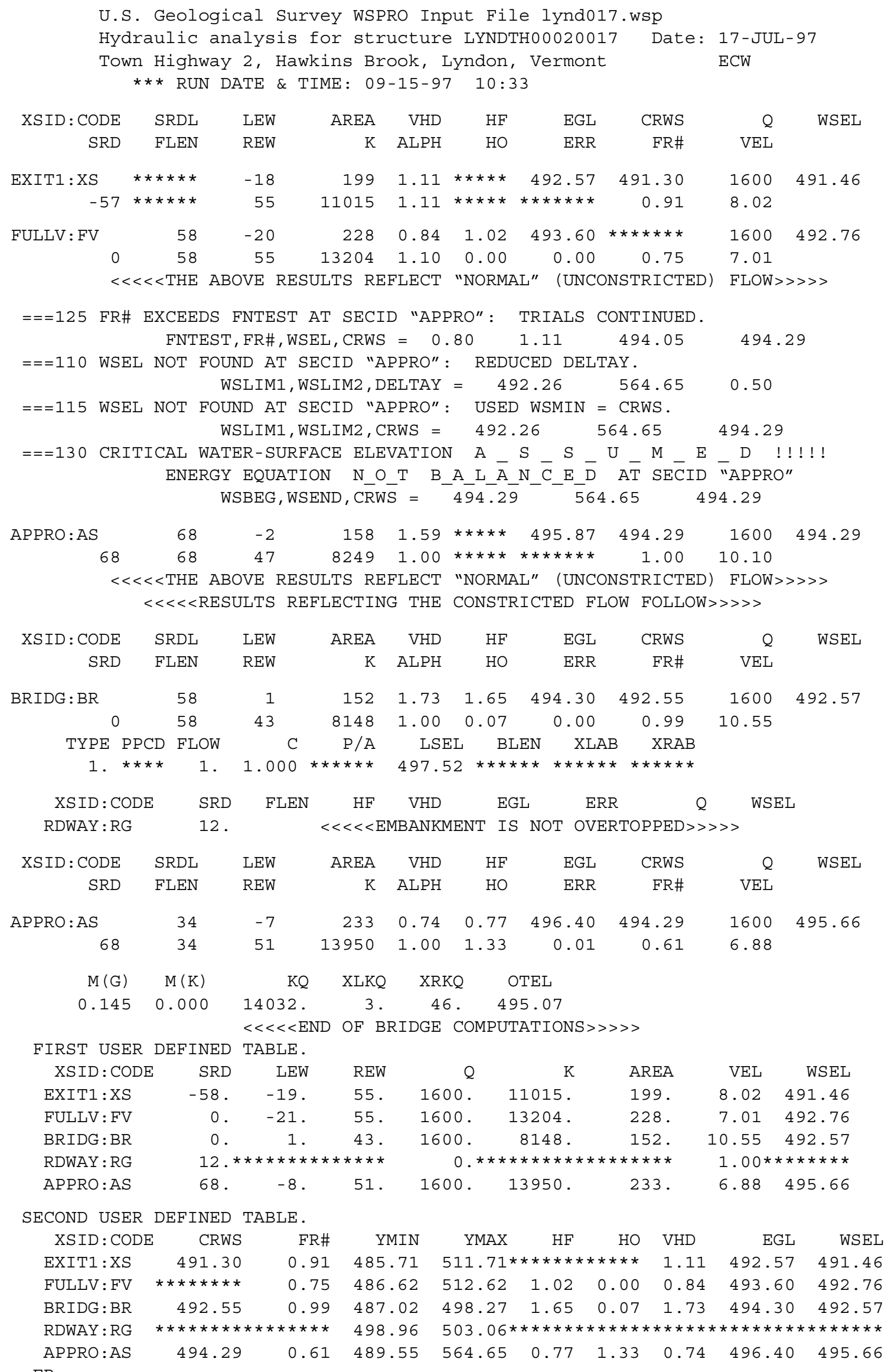

NORMAL END OF WSPRO EXECUTION. 


\section{APPENDIX C:}

\section{BED-MATERIAL PARTICLE-SIZE DISTRIBUTION}




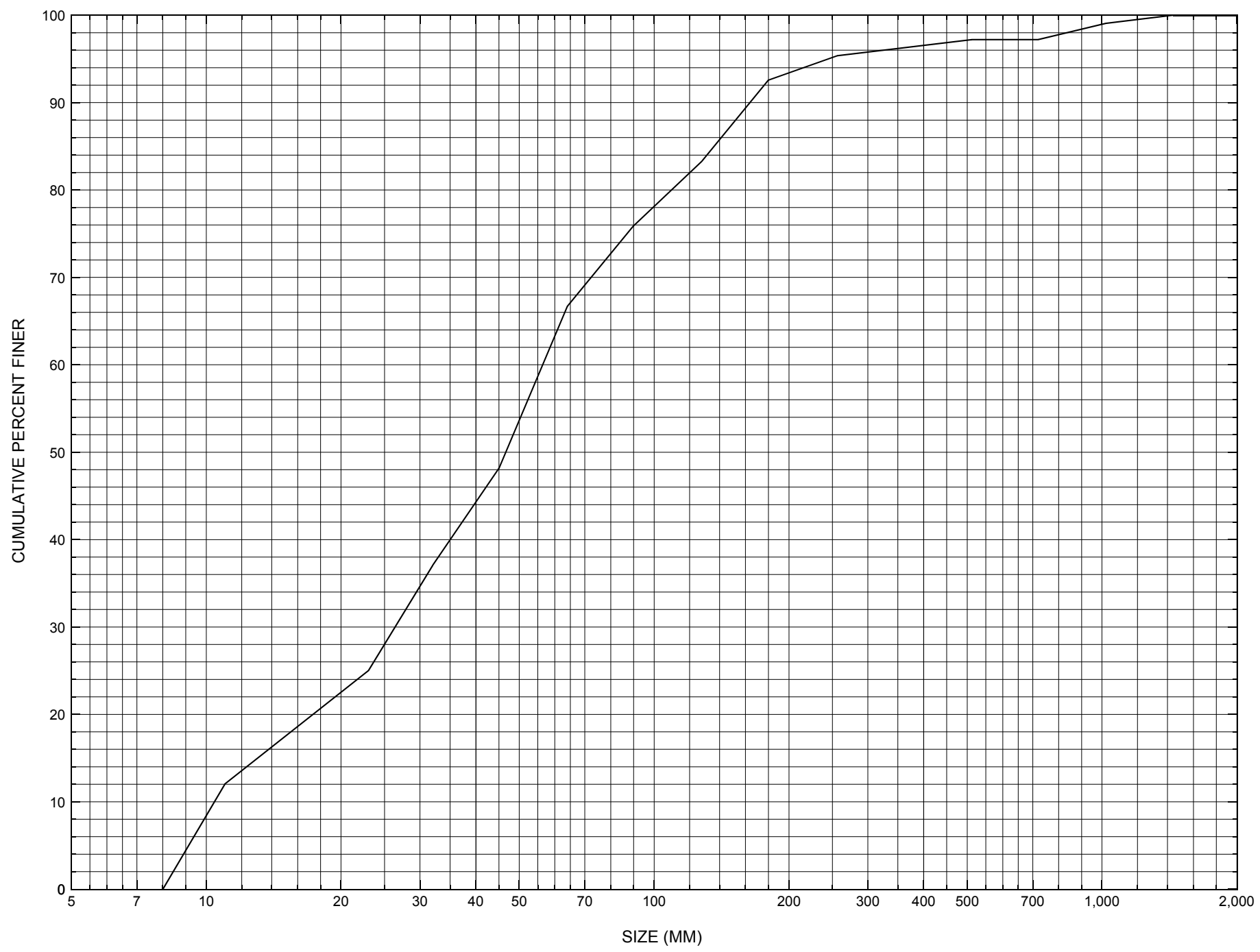

Appendix C. Bed material particle-size distribution for a pebble count in the channel approach of structure LYNDTH00020017, in Lyndon, Vermont. 


\section{APPENDIX D: \\ HISTORICAL DATA FORM}




\section{Structure Number LYNDTH00020017}

\section{General Location Descriptive}

Data collected by (First Initial, Full last name) $\underline{\mathbf{E}}$. BOEHMLER

Date $(M M / D D / Y Y) \_\mathbf{0 3} / \underline{27} / \underline{95}$

Highway District Number (I - 2; nn) $\mathbf{0 7}$

Town (FIPS place code; I - 4; nnnnn) $\mathbf{4 1 7 2 5}$

Waterway (I - 6) HAWKINS BROOK

Route Number $\mathbf{\text { TH002 }}$

Topographic Map Burke Mountain

Latitude (I - 16; nnnn.n) $\mathbf{4 4 3 0 7}$
County (FIPS county code; I - 3; nnn)

Mile marker (I - 11; nnn.nnn) $\mathbf{0 0 0 0 0 0}$

Road Name (I - 7): -

Vicinity (I - 9) 0.15 MI TO JCT W C3 TH75

Hydrologic Unit Code: $\mathbf{0 1 0 8 0 1 0 2}$

Longitude (i - 17; nnnnn.n) $\mathbf{7 1 5 7 6}$

\section{Select Federal Inventory Codes}

FHWA Structure Number (I - 8) 10030700170307

Maintenance responsibility $(I-21 ; n n) \_$03 _ Maximum span length $(I-48$; $n n n n) \underline{\mathbf{0 0 4 6}}$

Year built (I - 27; YYYY) 1928

Structure length (I - 49; nnnnnn) $\underline{000049}$

Average daily traffic, ADT (I - 29; nnnnnn) 000650

Deck Width (I - 52; nn.n) 231

Year of ADT (I - 30; YY) $\mathbf{9 2}$

Channel \& Protection $(I-61 ; n) \underline{\mathbf{5}}$

Opening skew to Roadway $(I-34 ; n n) \quad \mathbf{0 5}$

Waterway adequacy $(I-71 ; n) \underline{6}$

Operational status $(I-41 ; X) \quad \mathbf{A}$

Underwater Inspection Frequency $(I-92 B ; X Y Y) \_\mathbf{N}$

Structure type (I- 43; nnn) $\mathbf{3 0 2}$

Year Reconstructed (I - 106) 1974

Approach span structure type (I - 44; nnn) $\mathbf{0 0 0}$

Clear span (nnn.n ft)

Number of spans (I - 45; nnn) $\mathbf{0 0 1}$

Vertical clearance from streambed (nnn.n ft) $\underline{\mathbf{0 0 7 . 7}}$

Number of approach spans (I - 46; nnnn) $\underline{\mathbf{0 0 0 0}}$ Waterway of full opening $\left(n n n . n \mathrm{ft}^{2}\right) \underline{\mathbf{3 3 6 . 0}}$

Comments:

The structural inspection report of 10/31/94 indicates the structure is a steel stringer type bridge with a concrete deck. The abutment walls and wingwalls are constructed of concrete. The concrete footing is exposed on the left abutment. The LABUT reportedly is fairly new. The LABUT wall has a few fine cracks and small leaks at the up- and downstream ends and its wingwalls. A low, coarse gravel point bar is reported in the channel along the right abutment and blocks one third of the channel. The report indicates that most of the flow is against the upstream end of the LABUT. Some boulder and stone fill is noted in front of the right abutment and on all of the wingwalls. (Continued, page 31) 


\section{Bridge Hydrologic Data}

Is there hydrologic data available? $\underline{\mathbf{N}}$ if No, type ctrl-n $h \quad$ VTAOT Drainage area $\left(m i^{2}\right)$ : -

Terrain character:

Stream character \& type: -

Streambed material:

Discharge Data (cfs):

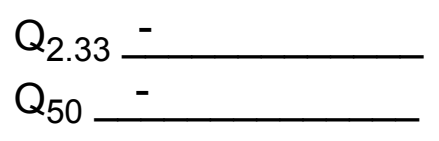

Record flood date $(M M / D D / Y Y):-{ }^{\prime}-$
Estimated Discharge $(c f s):-$

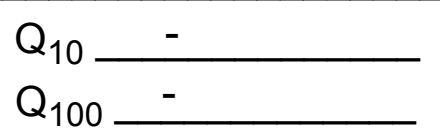

$\mathrm{Q}_{25}$

Water surface elevation $(f t):-$ $(\mathrm{ft} / \mathrm{s}):$

Ice conditions (Heavy, Moderate, Light) : -

Debris (Heavy, Moderate, Light):

The stage increases to maximum highwater elevation (Rapidly, Not rapidly):

The stream response is (Flashy, Not flashy):

Describe any significant site conditions upstream or downstream that may influence the stream's stage: -

Watershed storage area (in percent):

The watershed storage area is: - (1-mainly at the headwaters; 2- uniformly distributed; 3-immediatly upstream oi the site)

Water Surface Elevation Estimates for Existing Structure:

\begin{tabular}{|l|l|l|l|l|l|}
\hline Peak discharge frequency & $Q_{2.33}$ & $Q_{10}$ & $Q_{25}$ & $Q_{50}$ & $Q_{100}$ \\
Water surface elevation (ft)) & - & - & - & - & - \\
Velocity (ft/sec) & - & - & - & - & - \\
\hline
\end{tabular}

Long term stream bed changes: -

Is the roadway overtopped below the $\mathrm{Q}_{100}$ ? (Yes, No, Unknown): $\mathbf{U}$ Frequency: -

Relief Elevation (ft):

Discharge over roadway at $Q_{100}\left(f^{3} / \mathrm{sec}\right)$ :

Are there other structures nearby? (Yes, No, Unknown):

Upstream distance (miles):

Town: If No or Unknown, type ctrl-n os

Highway No. : Structure No. : Year Built:

Clear span (ft): Clear Height $(f t)$ : Full Waterway $\left(f^{2}\right)$ : 
Downstream distance (miles): Town: Year Built:

Highway No. : Structure No. : Structure Type:

Clear span (ft): Clear Height $(f t)$ : Full Waterway $\left(f^{2}\right)$ :

Comments:

There is some stone fill reported on the banks upstream and downstream. The report notes that there has been no undermining or significant signs of settling. Debris accumulation is noted as minor at this site.

\section{USGS Watershed Data}

Watershed Hydrographic Data

Drainage area $(D A)$ $\mathrm{mi}^{2}$ Lake/pond/swamp area 0.082 $\mathrm{mi}^{2}$

Watershed storage (ST) 1.1

Bridge site elevation 855 $\mathrm{ft}$ $\%$

Main channel length 4.47 mi $10 \%$ channel length elevation 890 $\mathrm{ft} \quad 85 \%$ channel length elevation 1720 $\mathrm{ft}$

Main channel slope $(S)$ (S) 247.1 $\mathrm{ft} / \mathrm{mi}$

Watershed Precipitation Data

Average site precipitation in Average headwater precipitation in

Maximum 2yr-24hr precipitation event $(124,2)$ in

Average seasonal snowfall (Sn) $\mathrm{ft}$ 


\section{Bridge Plan Data}

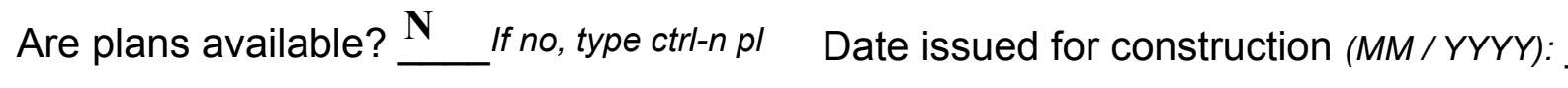

Project Number

Minimum channel bed elevation:

Low superstructure elevation: USLAB DSLAB USRAB DSRAB Benchmark location description:

NO BENCKMARK INFORMATION

Reference Point (MSL, Arbitrary, Other): Datum (NAD27, NAD83, Other):

Foundation Type: 4

If 1 : Footing Thickness

If 2: Pile Type:

If 3: Footing bottom elevation:

Is boring information available? $\mathbf{N}$

Foundation Material Type: $\mathbf{3}$

(1-Spreadfooting; 2-Pile; 3- Gravity; 4-Unknown)

Footing bottom elevation: -

Briefly describe material at foundation bottom elevation or around piles:

NO DRILL BORING INFORMATION

Comments: 


\section{Cross-sectional Data}

Is cross-sectional data available? $\underline{\mathbf{Y}}$ If no, type ctrl-n xs

Source (FEMA, VTAOT, Other)? VTAOT

Comments: This cross-section is the upstream face. The low cord elevations are from the survey log done for this report on 8/4/95. The low cord to bed length data is from the sketch attached to a bridge inspection report dated 10/31/94. The sketch was done on 6/9/92.

\begin{tabular}{|l|l|l|l|l|l|l|l|l|l|l|l|}
\hline Station & $\mathbf{0}$ & $\mathbf{1 5 . 3}$ & $\mathbf{2 3 . 8}$ & $\mathbf{3 0 . 8}$ & $\mathbf{4 3 . 8}$ & - & - & - & - & - & - \\
\hline Feature & LAB & - & - & - & RAB & - & - & - & - & - & - \\
\hline $\begin{array}{l}\text { Low chord } \\
\text { elevation }\end{array}$ & $\mathbf{4 9 6 . 8}$ & $\mathbf{4 9 7 . 3}$ & $\mathbf{4 9 7 . 5}$ & $\mathbf{4 9 7 . 7}$ & $\mathbf{4 9 8 . 3}$ & - & - & - & - & - & - \\
\hline $\begin{array}{l}\text { Bed } \\
\text { elevation }\end{array}$ & $\mathbf{4 9 0 . 2}$ & $\mathbf{4 8 8 . 8}$ & $\mathbf{4 8 8 . 6}$ & $\mathbf{4 8 9 . 7}$ & $\mathbf{4 9 1 . 6}$ & - & - & - & - & - & - \\
\hline $\begin{array}{l}\text { Low chord- } \\
\text { bed }\end{array}$ & $\mathbf{6 . 6}$ & $\mathbf{8 . 5}$ & $\mathbf{8 . 9}$ & $\mathbf{8 . 0}$ & $\mathbf{6 . 7}$ & - & - & - & - & - & - \\
\hline Station & - & - & - & - & - & - & - & - & - & - & - \\
\hline Feature & - & - & - & - & - & - & - & - & - & - & - \\
\hline $\begin{array}{l}\text { Low chord } \\
\text { elevation }\end{array}$ & - & - & - & - & - & - & - & - & - & - & - \\
\hline $\begin{array}{l}\text { Bed } \\
\text { elevation }\end{array}$ & - & - & - & - & - & - & - & - & - & - & - \\
\hline $\begin{array}{l}\text { Low chord- } \\
\text { bed }\end{array}$ & - & - & - & - & - & - & - & - & - & - & - \\
\hline
\end{tabular}

Source (FEMA, VTAOT, Other)?

Comments:

\begin{tabular}{|l|l|l|l|l|l|l|l|l|l|l|l|}
\hline Station & - & - & - & - & - & - & - & - & - & - & - \\
\hline Feature & - & - & - & - & - & - & - & - & - & - & - \\
\hline $\begin{array}{l}\text { Low chord } \\
\text { elevation }\end{array}$ & - & - & - & - & - & - & - & - & - & - & - \\
\hline $\begin{array}{l}\text { Bed } \\
\text { elevation }\end{array}$ & - & - & - & - & - & - & - & - & - & - & - \\
\hline $\begin{array}{l}\text { Low chord- } \\
\text { bed }\end{array}$ & - & - & - & - & - & - & - & - & - & - & - \\
\hline Station & - & - & - & - & - & - & - & - & - & - & - \\
\hline Feature & - & - & - & - & - & - & - & - & - & - & - \\
\hline $\begin{array}{l}\text { Low chord } \\
\text { elevation }\end{array}$ & - & - & - & - & - & - & & - & - & - & - \\
\hline $\begin{array}{l}\text { Bed } \\
\text { elevation }\end{array}$ & - & - & - & - & - & - & - & - & - & - & - \\
\hline $\begin{array}{l}\text { Low chord- } \\
\text { bed }\end{array}$ & - & - & - & - & - & - & - & - & - & - & - \\
\hline
\end{tabular}




\section{APPENDIX E: \\ LEVEL I DATA FORM}


U. S. Geological Survey

Bridge Field Data Collection and Processing Form

Qa/Qc Check by: EW Date: $\underline{\mathbf{0 3} / \mathbf{0 1} / \mathbf{9 6}}$

\section{A. General Location Descriptive}

1. Data collected by (First Initial, Full last name) L. MEDALIE

Date $(M M / D D / Y Y) \mathbf{0 8} / \mathbf{0 4} / 1996$

2. Highway District Number $\mathbf{0 7}$

County CALEDONIA (005)

Waterway (l - 6) HAWKINS BROOK

Route Number TH002

3. Descriptive comments:

The bridge structure is a steel stringer with concrete deck and wingwalls. The bridge was built in 1928, but has been recently constructed with concrete (RABUT). It is located 0.15 miles from the junction with Town Highway 75.

\section{B. Bridge Deck Observations}
4. Surface cover... LBUS 6
RBUS 6
LBDS 5
RBDS 5
Overall 6

(2b us,ds,lb,rb: 1- Urban; 2- Suburban; 3- Row crops; 4- Pasture; 5- Shrub- and brushland; 6- Forest; 7- Wetland)
5. Ambient water surface... US 2
UB 2
DS $\underline{2}$
(1- pool; 2- riffle)

6. Bridge structure type 1 (1- single span; 2- multiple span; 3- single arch; 4- multiple arch; 5-cylindrical culvert; 6- box culvert; or 7- other)
7. Bridge length 49
(feet)
Span length $\underline{46}$
(feet)
Bridge width 23.1 (feet)

\section{Road approach to bridge:}
8. LB 1
RB 2
( 0 even, 1- lower, 2- higher)
9. LB
RB 1
(1- Paved, 2- Not paved)

10. Embankment slope (run / rise in feet / foot)

US left

US right

\begin{tabular}{|c|c|c|c|}
\hline \multicolumn{2}{|c|}{ Protection } & \multirow{2}{*}{ 13.Erosion } & 14.Severity \\
\hline 11.Type & 12.Cond. & $\mathbf{0}$ & - \\
\hline $\mathbf{0}$ & - & $\mathbf{0}$ & - \\
\hline $\mathbf{0}$ & - & $\mathbf{2}$ & - \\
\hline $\mathbf{0}$ & - & $\mathbf{0}$ & - \\
\hline $\mathbf{0}$ & - & $\mathbf{0}$ & - \\
\hline
\end{tabular}

Bank protection types: 0- none; 1- < 12 inches;

2- < 36 inches; 3- < 48 inches;

4- < 60 inches; 5- wall / artificial levee

Bank protection conditions: 1- good; 2- slumped;

3- eroded; 4- failed

Erosion: 0 - none; 1- channel erosion; 2 -

road wash; 3- both; 4- other

Erosion Severity: 0 - none; 1- slight; 2- moderate; 3- severe

\section{Channel approach to bridge (BF):}

15. Angle of approach: $\mathbf{6 5}$

16. Bridge skew: 45

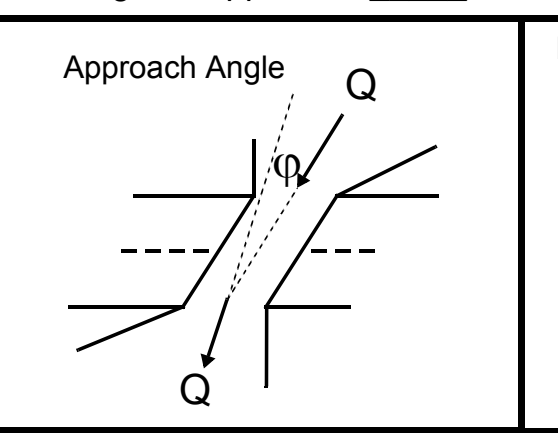

17. Channel impact zone 1 :

Where? LB (LB, RB)

Range? 30 feet US

Channel impact zone 2:

Where? $(L B, R B)$

Range? - $\quad$ feet (US, UB, DS) to feet -

Impact Severity: 0- none to very slight; 1- Slight; 2- Moderate; 3- Severe 
18. Bridge Type: 1a

1a- Vertical abutments with wingwalls

$1 \mathrm{~b}$ - Vertical abutments without wingwalls

2- Vertical abutments and wingwalls, sloping embankment Wingwalls parallel to abut. face

3- Spill through abutments

4- Sloping embankment, vertical wingwalls and abutments

Wingwall angle less than $90^{\circ}$.

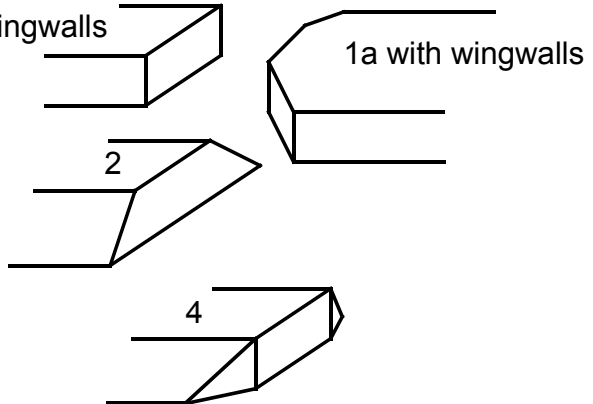

19. Bridge Deck Comments (surface cover variations, measured bridge and span lengths, bridge type variations, approach overflow width, etc.)

\#4: The downstream right bank has a strip of forest cover, 60-80 feet wide, from the bank and up the sloping overbank, then surface cover is pasture (lawn). The downstream left bank is mostly forest, but also fairly significant shrubbery, refer to report photos. A dirt driveway on the upstream left bank leads to house with small lawn, but this area is surounded by forest.

\#7: Values are from VTAOT. The measured bridge length is 49.8 feet, bridge span is 44.6 feet, and bridge width is $\mathbf{2 2 . 9}$ feet.

\#8: The measured road width is 19 feet about 12 feet from bridge.

\#11: Along the upstream right bank, type 2 boulders serve as protection

\section{Upstream Channel Assessment}

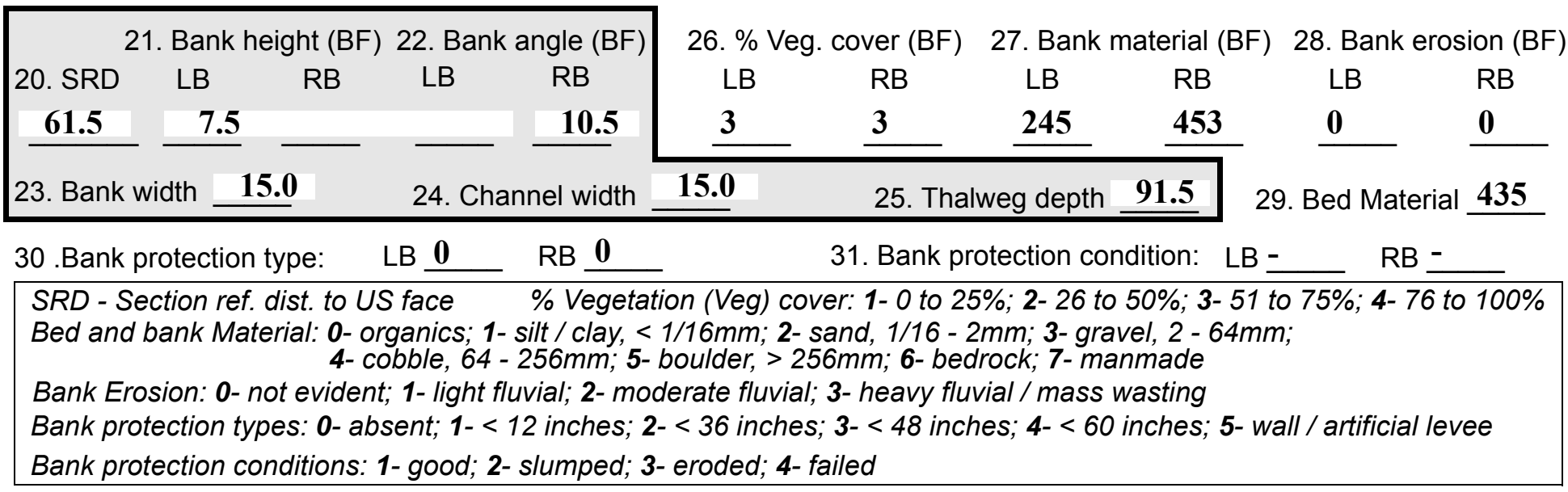

32. Comments (bank material variation, minor inflows, protection extent, etc.):

\#26: The right bank vegetation cover is zero percent from the bridge to 40 feet upstream, then the bank is fifty-one to seventy-five percent (category 3). 

36. Point bar extent: 30 feet $\underline{\mathbf{U S}}$ (US, UB) to $\underline{\mathbf{1 1 2}}$ feet $\underline{\mathbf{U S}}$ (US, UB, DS) positioned $\underline{\mathbf{6 5}} \%$ LB to $\underline{\mathbf{8 0}} \%$ RB 37. Material: $\mathbf{3 4 5}$

38. Point or side bar comments (Circle Point or Side; Note additional bars, material variation, status, etc.):

\#37: Bed material is unsorted.

A side bar is present on the LB from 92 to 132 feet US. The mid-bar distance is at 122 feet where it is $\mathbf{6}$ feet wide. The bed material is gravel, cobble and boulder. The bar is positioned $30 \% \mathrm{LB}$ to $40 \% \mathrm{RB}$.
39. Is a cut-bank present? Y
( $Y$ or if $N$ type $c$ trl-n $c b)$
40. Where? $\underline{\text { LB }}$ (LB or RB)

41. Mid-bank distance: $\mathbf{7 8}$

42. Cut bank extent: 70

43. Bank damage: 1

(1- eroded and/or creep; 2- slip failure; 3- block failure)

44. Cut bank comments (eg. additional cut banks, protection condition, etc.):

45. Is channel scour present? $\mathbf{N}$ ( $Y$ or if $N$ type ctrl-n cs)

47. Scour dimensions: Length Width -

Depth : -

46. Mid-scour distance: -

48. Scour comments (eg. additional scour areas, local scouring process, etc.):

\section{NO CHANNEL SCOUR}

\section{Local channel scour exists behind boulders}

49. Are there major confluences? $\mathbf{N}$ (Y or if $N$ type ctrl-n $m c$ )

51. Confluence 1: Distance -

Confluence 2: Distance -
52. Enters on -

Enters on ( $L B$ or $R B)$ (LB or $R B)$

54. Confluence comments (eg. confluence name):

NO MAJOR CONFLUENCES

A minor confluence exists at 30 feet US on the $L B$. It is ephemeral.

\section{Under Bridge Channel Assessment}

55. Channel restraint (BF)? LB 2 (1- natural bank; 2- abutment; 3- artificial levee)

\begin{tabular}{|ccccc}
\multicolumn{2}{|c}{56. Height (BF) } & \multicolumn{3}{c}{57 Angle (BF) } \\
LB & RB & LB & RB \\
$\mathbf{3 0 . 5}$ & & & $\mathbf{1 . 0}$ & \\
\hline
\end{tabular}

58. Bank width (BF) -

59. Channel width -

61. Material (BF)

LB RB

$\underline{2} \quad \underline{7}$
62. Erosion (BF)

LB RB

7
53. Type(1- perennial; 2- ephemeral)

Type (1-perennial; 2- ephemeral)

Bed and bank Material: 0- organics; 1- silt / clay, < 1/16mm; 2- sand, 1/16 - 2mm; 3- gravel, 2 - 64mm; 4- cobble, 64 - 256mm; 5- boulder, > 256mm; 6- bedrock; 7- manmade

Bank Erosion: 0- not evident; 1- light fluvial; 2- moderate fluvial; 3- heavy fluvial / mass wasting

64. Comments (bank material variation, minor inflows, protection extent, etc.):

435

Bed slopes down slightly from the RABUT towards the LABUT. 
65. Debris and Ice Is there debris accumulation?

(Yor $N)$ 66. Where? $\underline{Y}$

(1- Upstream; 2- At bridge; 3- Both)

67. Debris Potential $\underline{3}$

(1-Low; 2- Moderate; 3- High)

68. Capture Efficiency 1

(1-Low; 2- Moderate; 3- High)

69. Is there evidence of ice build-up? 1 (Y or $N)$

Ice Blockage Potential $\mathbf{N}$

(1-Low; 2- Moderate; 3- High)

70. Debris and Ice Comments:

1

\#65: A very, very slight amount of debris accumulation both US and at the bridge; twigs are caught behind boulders and on the protruding low steel

\begin{tabular}{|l|c|c|c|c|c|c|c|c|}
\hline Abutments & $\begin{array}{c}\text { 71. Attack } \\
\angle \text { (BF) }\end{array}$ & $\begin{array}{c}72 \text {. Slope } \angle \\
\text { (Qmax) }\end{array}$ & $\begin{array}{c}\text { 73. Toe } \\
\text { loc. (BF) }\end{array}$ & $\begin{array}{c}\text { 74. Scour } \\
\text { Condition }\end{array}$ & $\begin{array}{c}75 . \text { Scour } \\
\text { depth }\end{array}$ & $\begin{array}{c}\text { 76. Exposure } \\
\text { depth }\end{array}$ & 77. Material & 78. Length \\
\hline LABUT & & $\mathbf{5 0}$ & $\mathbf{8 5}$ & $\mathbf{2}$ & $\mathbf{2}$ & $\mathbf{0 . 7 5}$ & $\mathbf{3}$ & $\mathbf{9 0 . 0}$ \\
\hline RABUT & $\mathbf{1}$ & $\mathbf{0}$ & $\mathbf{8 5}$ & & & $\mathbf{2}$ & $\mathbf{0}$ & $\mathbf{4 3 . 5}$ \\
\hline
\end{tabular}

Pushed: $L B$ or RB

Toe Location (Loc.): 0- even, 1- set back, 2- protrudes

Scour cond.: 0- not evident; 1- evident (comment); 2- footing exposed; 3-undermined footing; 4- piling exposed; 5- settled; 6- failed

Materials: 1- Concrete; 2- Stone masonry or drywall; 3- steel or metal; 4- wood

79. Abutment comments (eg. undermined penetration, unusual scour processes, debris, etc.):

$-$

1

\#75: The average thalweg is 0.5 feet. Since the water depth is 1.25 feet at the scour hole, the scour depth is 0.75 feet. Scour at the LABUT begins midway under bridge to the DS end.

\#76: The LABUT exposure depth grades from 3 feet at the DS end to 0.3 feet at the US end.

80. Wingwalls:

Exist? Material? Scour Scour Exposure $\begin{aligned} & 81 . \\ & \text { Angle? Length? }\end{aligned}$ Condition? depth? depth?

USLWW:

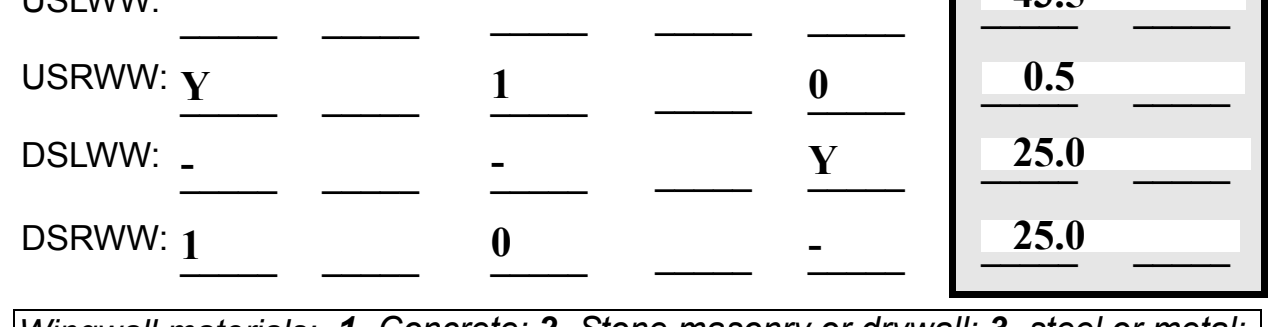

Wingwall materials: 1- Concrete; 2- Stone masonry or drywall; 3- steel or metal; 4- wood

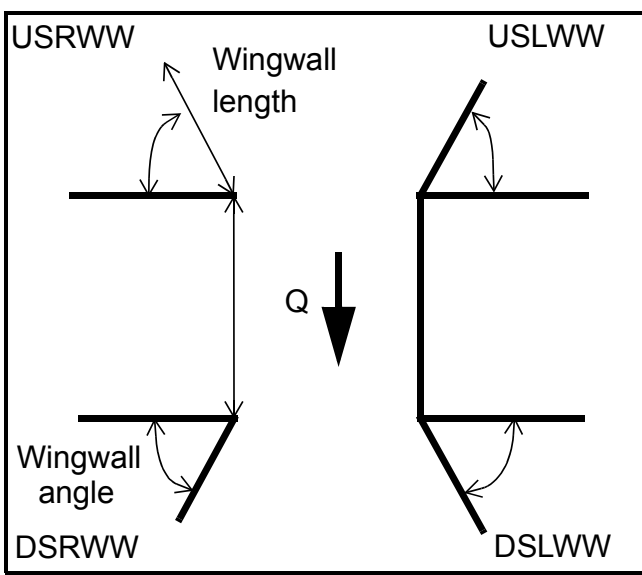

82. Bank / Bridge Protection:

\begin{tabular}{|l|l|l|l|l|l|l|c|c|}
\hline Location & USLWW & USRWW & LABUT & RABUT & LB & RB & DSLWW & DSRWW \\
\hline Type & - & $\mathbf{2}$ & $\mathbf{Y}$ & - & - & - & - & $\mathbf{1}$ \\
\hline Condition & $\mathbf{Y}$ & $\mathbf{1}$ & $\mathbf{1}$ & - & - & - & - & $\mathbf{4}$ \\
\hline Extent & $\mathbf{1}$ & $\mathbf{3}$ & $\mathbf{0}$ & $\mathbf{0}$ & $\mathbf{0}$ & $\mathbf{0}$ & $\mathbf{5}$ & - \\
\hline
\end{tabular}

Bank / Bridge protection types: 0- absent; 1-<12 inches; 2- < 36 inches; 3- < 48 inches; 4- < 60 inches; 
83. Wingwall and protection comments (eg. undermined penetration, unusual scour processes, etc.):

-
-
-
-
-
2
1
2
0
-
-

\section{Piers:}

84. Are there piers? \#80 (Y or if $N$ type ctrl-n pr)

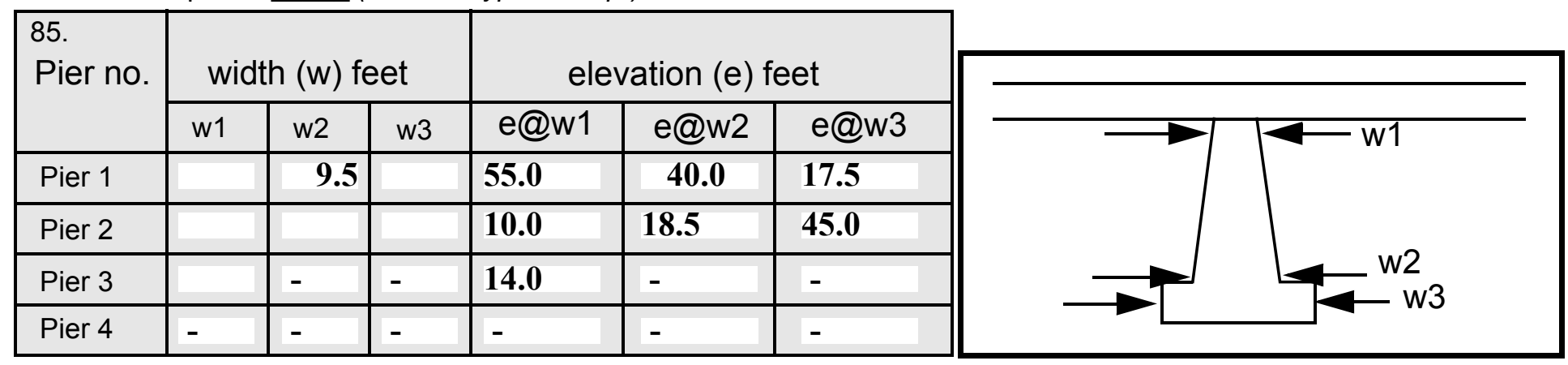

\begin{tabular}{|l|l|l|l|l|}
\hline Level 1 Pier Descr. & \multicolumn{1}{|c|}{1} & \multicolumn{1}{|c|}{2} & \multicolumn{1}{|c|}{3} & \multicolumn{1}{|c|}{4} \\
\hline 86. Location (BF) & :Along & adja- & bank & a pile \\
\hline 87. Type & the & cent & at 30 & of \\
\hline 88. Material & DSL & with & degr & strea \\
\hline 89. Shape & WW, & the & ees. & mbe \\
\hline 90. Inclined? & scou & LAB & \#82: & d \\
\hline 91. Attack $\angle$ (BF) & r is & UT. & Alon & mate \\
\hline 92. Pushed & only & The & g the & rial \\
\hline 93. Length (feet) & - & - & - & - \\
\hline 94. \# of piles & pres- & foot- & USL & is \\
\hline 95. Cross-members & ent & ing & WW & agai \\
\hline 96. Scour Condition & at & slope & and & nst \\
\hline 97. Scour depth & cor- & s up & LAB & the \\
\hline 98. Exposure depth & ner & with & UT, & wing \\
\hline
\end{tabular}

LFP, LTB, LB, MCL, MCM, MCR, RB, RTB, RFP

1- Solid pier, 2- column, 3- bent

1-Wood; 2- concrete; 3- metal; 4- stone

1- Round; 2- Square; 3- Pointed

Y-yes; $N$ - no

$L B$ or $R B$

0- none; 1- laterals; 2- diagonals; 3- both

0- not evident; 1- evident (comment);

2- footing exposed; 3- piling exposed;

4- undermined footing; 5- settled; 6- failed 
99. Pier comments (eg. undermined penetration, protection and protection extent, unusual scour processes, etc.):

wall, forming a small talus pile. The material serves as protection, and extends halfway across the LABUT.

*Along the RABUT three piles of cobbles have been placed against the abutment wall.

$\mathbf{N}$

$-$

100.

\section{E. Downstream Channel Assessment}

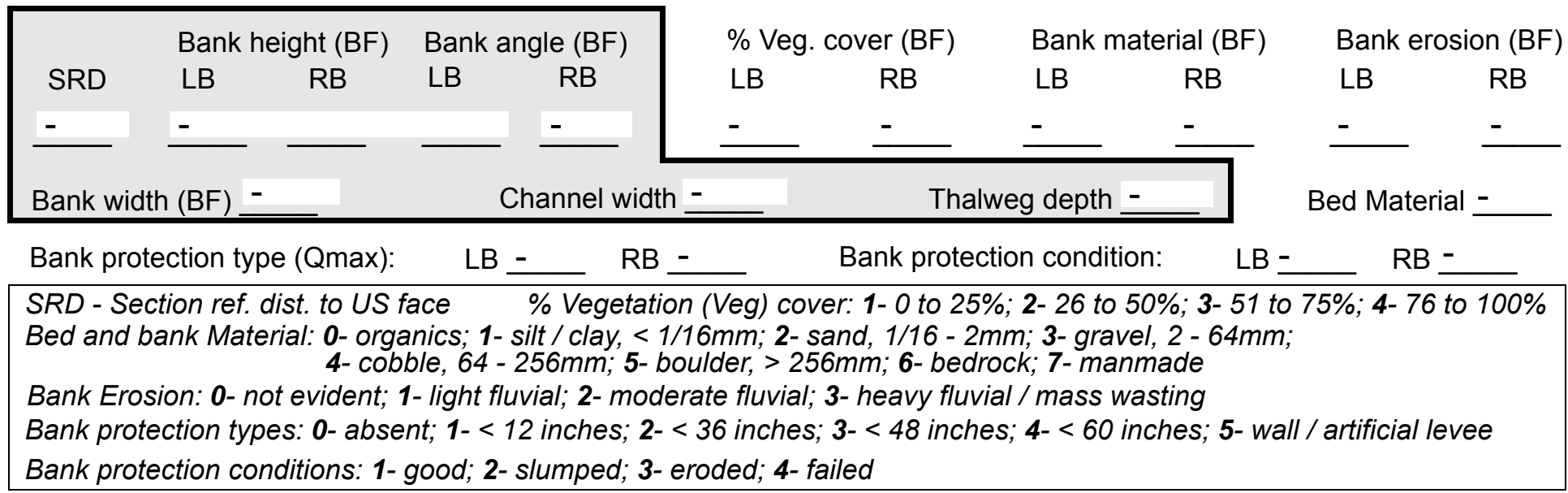

Comments (eg. bank material variation, minor inflows, protection extent, etc.):

$-$

$-$

$-$

$-$

$-$

$-$

$-$

$-$

$-$

$-$

$-$

$-$

101. Is a drop structure present? _ ( $Y$ or $N$, if $N$ type ctrl-n ds) 102. Distance: ___ feet
103. Drop: - feet
104. Structure material: -
(1- steel sheet pile; 2- wood pile; 3- concrete; 4- other)

105. Drop structure comments (eg. downstream scour depth):

$-$

-

$-$

$-$ 
106. Point/Side bar present? (Y or $N$. if $N$ type ctrl-n pb)Mid-bar distance:

Mid-bar width: -

Point bar extent: feet -

(US, UB, DS) to feet (US, UB, DS) positioned \%LB to $\%$ RB Material:

Point or side bar comments (Circle Point or Side; note additional bars, material variation, status, etc.):

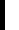

$-$

$-$

\section{NO PIERS}

Is a cut-bank present? ( $Y$ or if $N$ type ctrl- $n$ cb) Where? (LB or $R B)$

Mid-bank distance:

Cut bank extent: feet (US, UB, DS) to feet (US, UB, DS)

Bank damage: (1- eroded and/or creep; 2- slip failure; 3- block failure)

Cut bank comments (eg. additional cut banks, protection condition, etc.):

\section{2 \\ 2}

5432

Is channel scour present? $\underline{\mathbf{4 5 3}}$ ( $Y$ or if $N$ type ctrl-n cs) Mid-scour distance: $\underline{\mathbf{0}}$ Scour dimensions: Length $\underline{\mathbf{0}}$ Width $\underline{\mathbf{4 3 5 2}}$ Depth: $\underline{\mathbf{0}} \quad$ Positioned $\mathbf{0} \%$ LB to - $\%$ RB Scour comments (eg. additional scour areas, local scouring process, etc.):

$-$

$-$

Are there major confluences? ( $Y$ or if $N$ type ctrl-n $m c)$

How many?

Confluence 1: Distance

Enters on ( $L B$ or $R B)$

Type (1-perennial; 2- ephemeral)

Confluence 2: Distance

Enters on ( $L B$ or $R B)$

Type (1- perennial; 2- ephemeral)

Confluence comments (eg. confluence name):

\section{F. Geomorphic Channel Assessment}

107. Stage of reach evolution
1- Constructed

2- Stable

3- Aggraded

4- Degraded

5- Laterally unstable

6- Vertically and laterally unstable 
108. Evolution comments (Channel evolution not considering bridge effects; See HEC-20, Figure 1 for geomorphic descriptors):

$\mathbf{N}$

$-$

NO DROP STRUCTURE

Y

9

15

$\mathbf{0}$ 


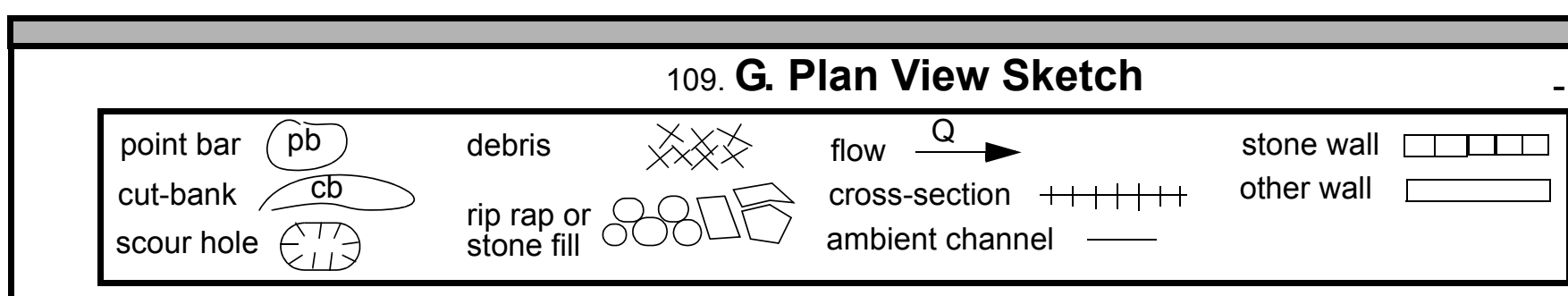

cut-bank

scour hole rip rap or
stone fill cross-section $+1+1+1$ ambient channe other wall 
APPENDIX F:

SCOUR COMPUTATIONS 


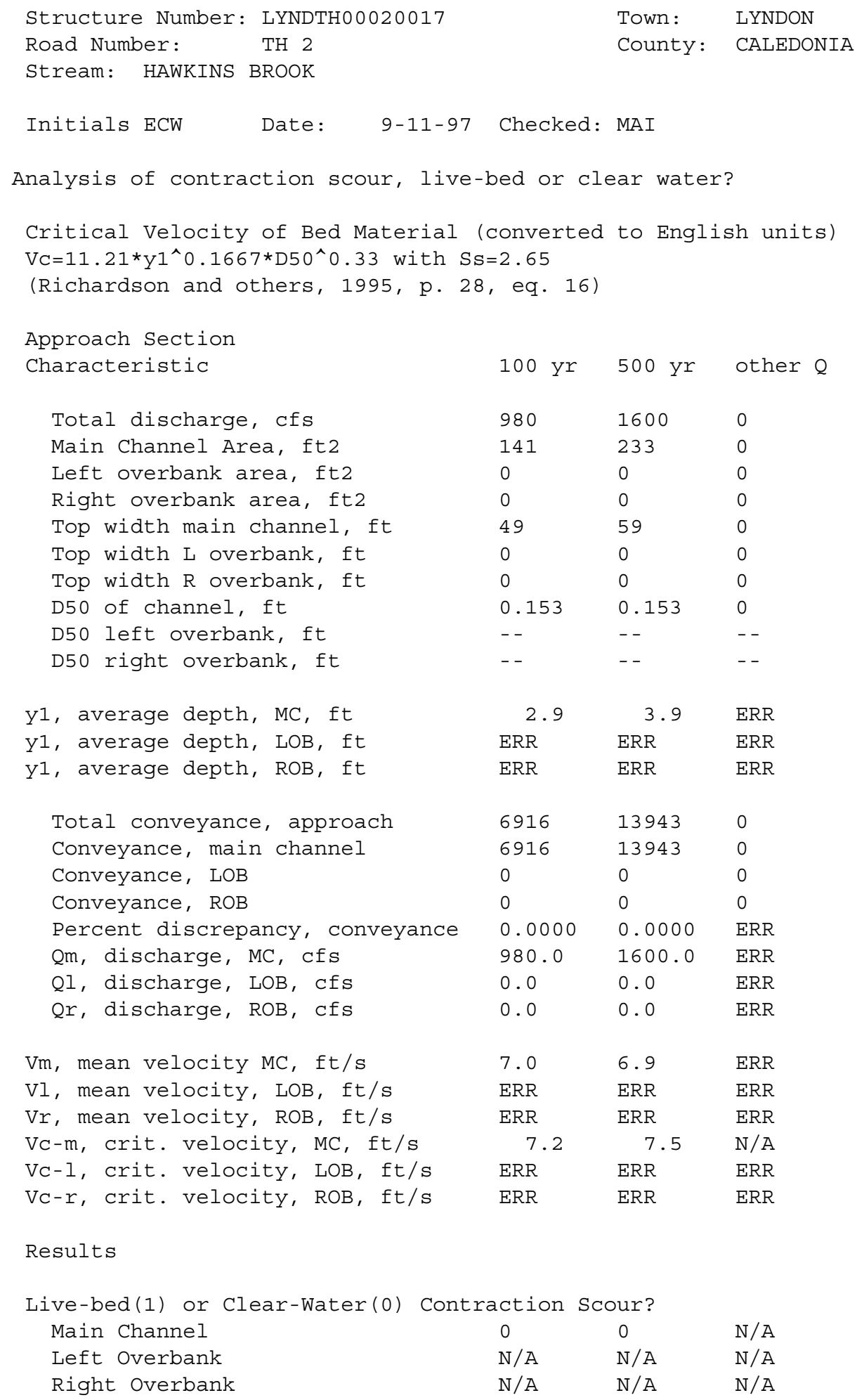

$\begin{array}{lll}0 & 0 & 0\end{array}$

$\begin{array}{lll}0 & 0 & 0\end{array}$


Clear water Contraction Scour in MAIN CHANNEL

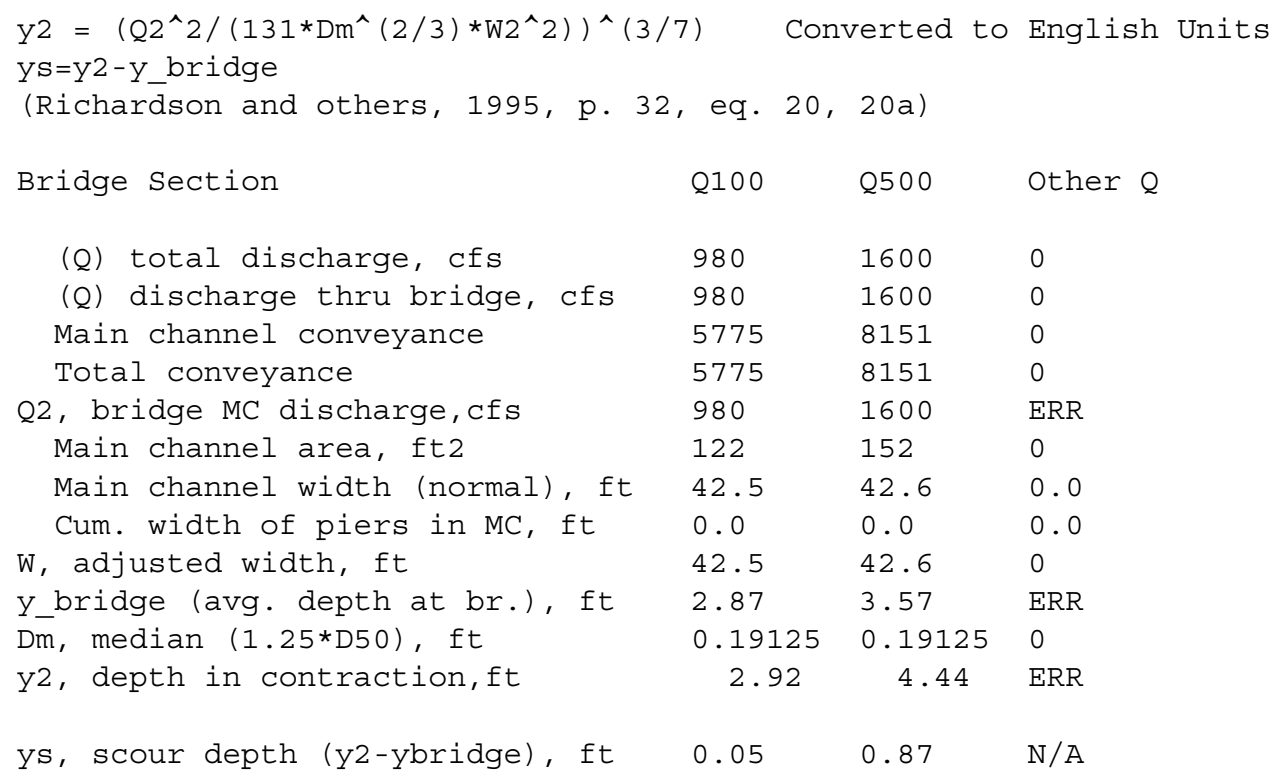

\begin{tabular}{|c|c|c|c|}
\hline \\
\hline \multicolumn{4}{|c|}{$\begin{array}{l}\text { Armoring } \\
\mathrm{DC}=\left[\left(1.94 * \mathrm{~V}^{\wedge} 2\right) /(5.75 * \log (12.27 * \mathrm{Y} / \mathrm{D} 90)) \wedge 2\right] /[0.03 *(165-62.4)] \\
\text { Depth to Armoring }=3 *(1 / \mathrm{PC}-1)\end{array}$} \\
\hline Downstream bridge face property & $100-y r$ & $500-y r$ & Other Q \\
\hline Q, discharge thru bridge $M C$, cfs & 980 & 1600 & $\mathrm{~N} / \mathrm{A}$ \\
\hline Main channel area (DS), ft2 & 122 & 152 & 0 \\
\hline Main channel width (normal), ft & 42.5 & 42.6 & 0.0 \\
\hline Cum. width of piers, ft & 0.0 & 0.0 & 0.0 \\
\hline Adj. main channel width, ft & 42.5 & 42.6 & 0.0 \\
\hline D90, ft & 0.5368 & 0.5368 & 0.0000 \\
\hline D95, ft & 0.8014 & 0.8014 & 0.0000 \\
\hline Dc, critical grain size, ft & 0.3726 & 0.5781 & ERR \\
\hline Pc, Decimal percent coarser than DC & 0.192 & 0.080 & 0.000 \\
\hline o armoring, ft & 4.71 & 19.97 & ERR \\
\hline
\end{tabular}


Abutment Scour

Froehlich's Abutment Scour

$\mathrm{Ys} / \mathrm{Y} 1=2.27 * \mathrm{~K} 1 * \mathrm{~K} 2 *\left(\mathrm{a}^{\prime} / \mathrm{Y} 1\right) \wedge 0.43 * \mathrm{Fr} 1 \wedge 0.61+1$

(Richardson and others, 1995, p. 48, eq. 28)

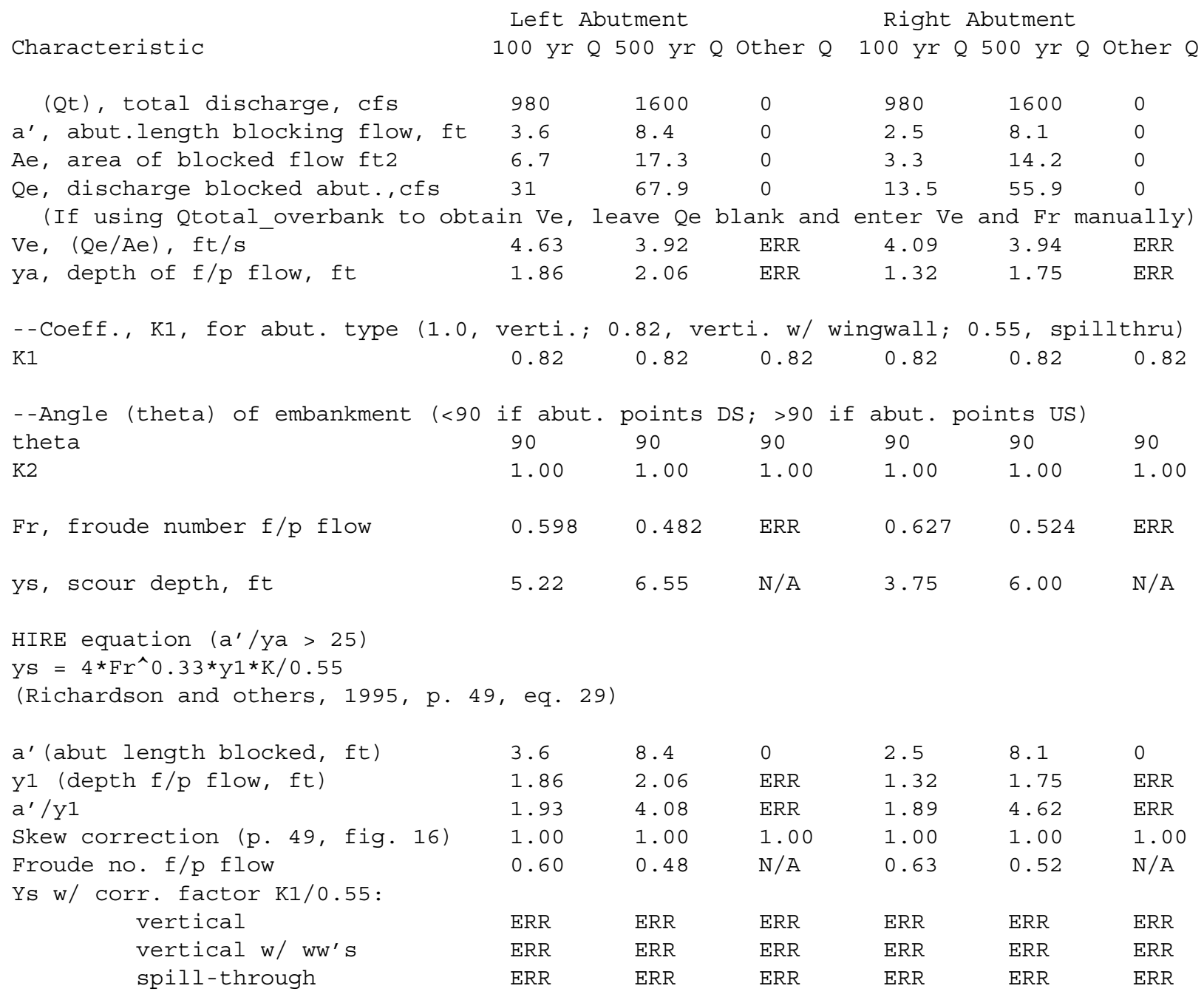




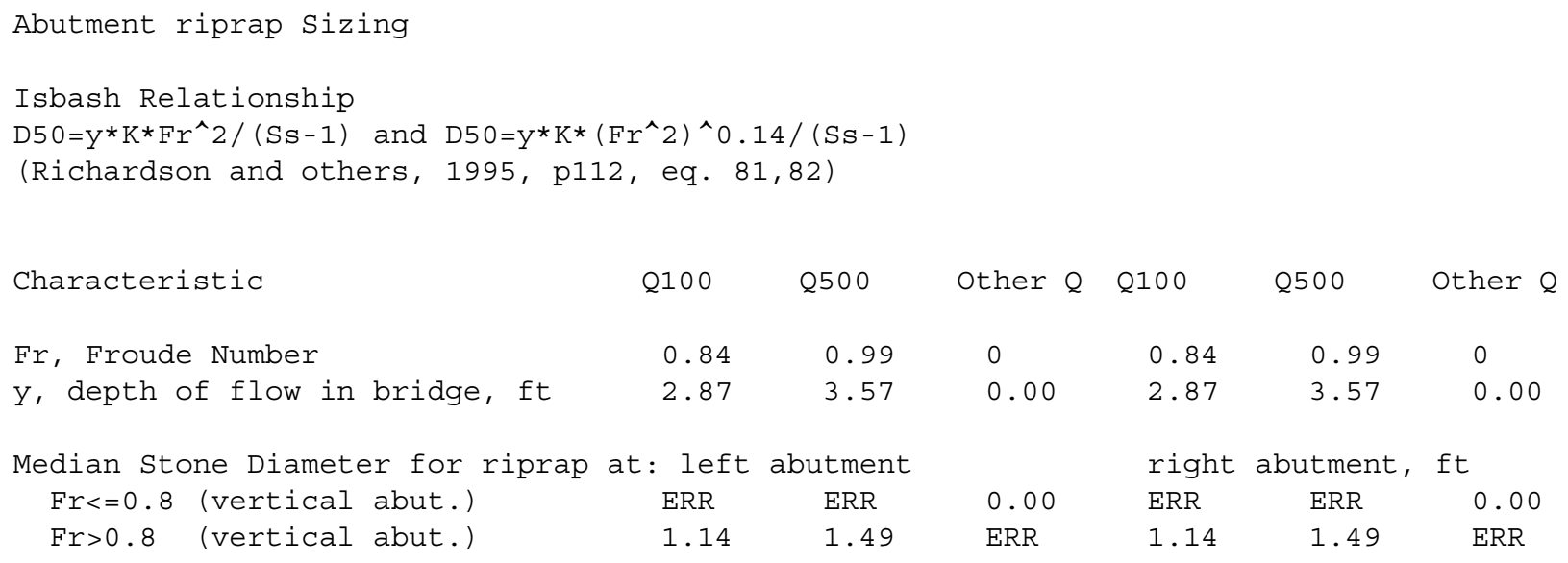

